\title{
Mesozoic sedimentary and magmatic evolution of the Arabian continental margin, northern Syria: evidence from the Baer-Bassit Melange
}

\author{
KHALIL AL-RIYAMI* \& ALASTAIR ROBERTSON† \\ Department of Geology and Geophysics, University of Edinburgh, Edinburgh EH9 3JW, UK
}

(Received 11 June 2001; accepted 2 April 2002)

\begin{abstract}
One of the few detailed records of Mesozoic deep-water sedimentation and volcanism preserved along the tectonically emplaced Arabian continental margin is from the Baer-Bassit region of northern Syria. South-Tethyan units there occur as blocks, broken formation and disrupted thrust sheets within the Bear-Bassit Melange. Two overall composite successions are identified. The first comprises mainly sedimentary successions ranging from Late Triassic to Late Cretaceous (Cenomanian) in age. The second is dominated by Middle Jurassic-Lower Cretaceous alkaline/ per-alkaline volcanic and minor intrusive igneous rocks. The extrusives are intercalated with radiolarian sediments and capped by Cenomanian ferromanganese-rich pelagic limestone. Facies comparisons and the regional setting suggest that the Triassic to Cenomanian, mainly sedimentary units, formed in deep water near the base of the slope of the Arabian continental margin. The contrasting volcanogenic successions developed in a more distal off-margin setting. Regional comparisons (e.g. with southwestern Cyprus and southwestern Turkey) suggest that continental break-up to form a South-Tethyan oceanic basin took place in Late Triassic time, associated with alkaline volcanism. Similar alkaline volcanism of Middle Jurassic to Early Cretaceous age could reflect the activity of a mantle plume beneath the Arabian plate. Overall, sedimentation was mainly controlled by an interplay of post-rift thermal subsidence, plume-related uplift, siliceous oceanic productivity, climatic change and eustatic sea-level change. The South-Tethyan marginal to oceanic units in northern Syria were detached from an inferred oceanic basement in latest Cretaceous time, emplaced onto the Arabian continental margin, then transgressed by Maastrichian and younger autochthonous successions.
\end{abstract}

Keywords: Tethys Sea; Mesogaea; Syria; ophiolite.

\section{Introduction}

During Mesozoic time the northern margin of the Arabian plate was bordered by a rifted continental margin adjacent to a South-Tethyan ocean ('Southern Neotethys'). This margin is well documented as the Hawasina Complex in Oman (Glennie et al. 1974; Robertson \& Searle, 1990), which was emplaced onto the Arabian margin in latest Cretaceous time but has not experienced strong collision-related deformation since. In addition, comparable marginal/oceanic units were emplaced in the latest Cretaceous along the Zagros suture zone, stretching from Iran adjacent to the Musandam Peninsula, to northern Syria bordering the easternmost Mediterranean Sea (Ricou, 1971; Fig. 1). Along this entire margin of Arabia, initial emplacement in latest Cretaceous time was followed by the collision of Arabia with Eurasia by midTertiary time, complicating the geological picture. In northern Syria, South-Tethyan margin/ocean units are represented by tectonically emplaced deep-sea

* Present address, Exploration Department (XEM/31), Petroleum Development Oman, P.O. Box 81, Muscat, Postal Code 113, Sultanate of Oman

†Author for correspondence: Alastair.Robertson@glg.ed.ac.uk sedimentary and volcanic units in the Baer-Bassit region (Figs 2, 3). Further west, a non-tectonically emplaced extension of the Mesozoic passive continental margin persists along the North African continental margin beneath the Mediterranean Sea (Garfunkel, 1998; Robertson, 1998).

The purpose of this paper is to summarize and interpret the evidence of the Mesozoic Arabian margin/oceanic units exposed in the Baer-Bassit region of northern Syria and to place these within the context of the South-Tethys.

\section{Regional tectonic setting}

Mesozoic deep-sea sedimentary and volcanic rocks are tectonically sandwiched between a Mesozoic carbonate platform below and oceanic-derived units, the Baer-Bassit Ophiolite, above (Dubertret, 1955; Kazmin \& Kulakov, 1968; Parrot, 1974a, 1980). The ophiolite is severely dismembered, but exposes all the units of a classic Tethyan ophiolite, including a metamorphic sole. Recent work on the Baer-Bassit Ophiolite, including its magmatic stratigraphy, sedimentary cover and structure are reported elsewhere (Al-Riyami et al. 2000; in press). The Mesozoic 


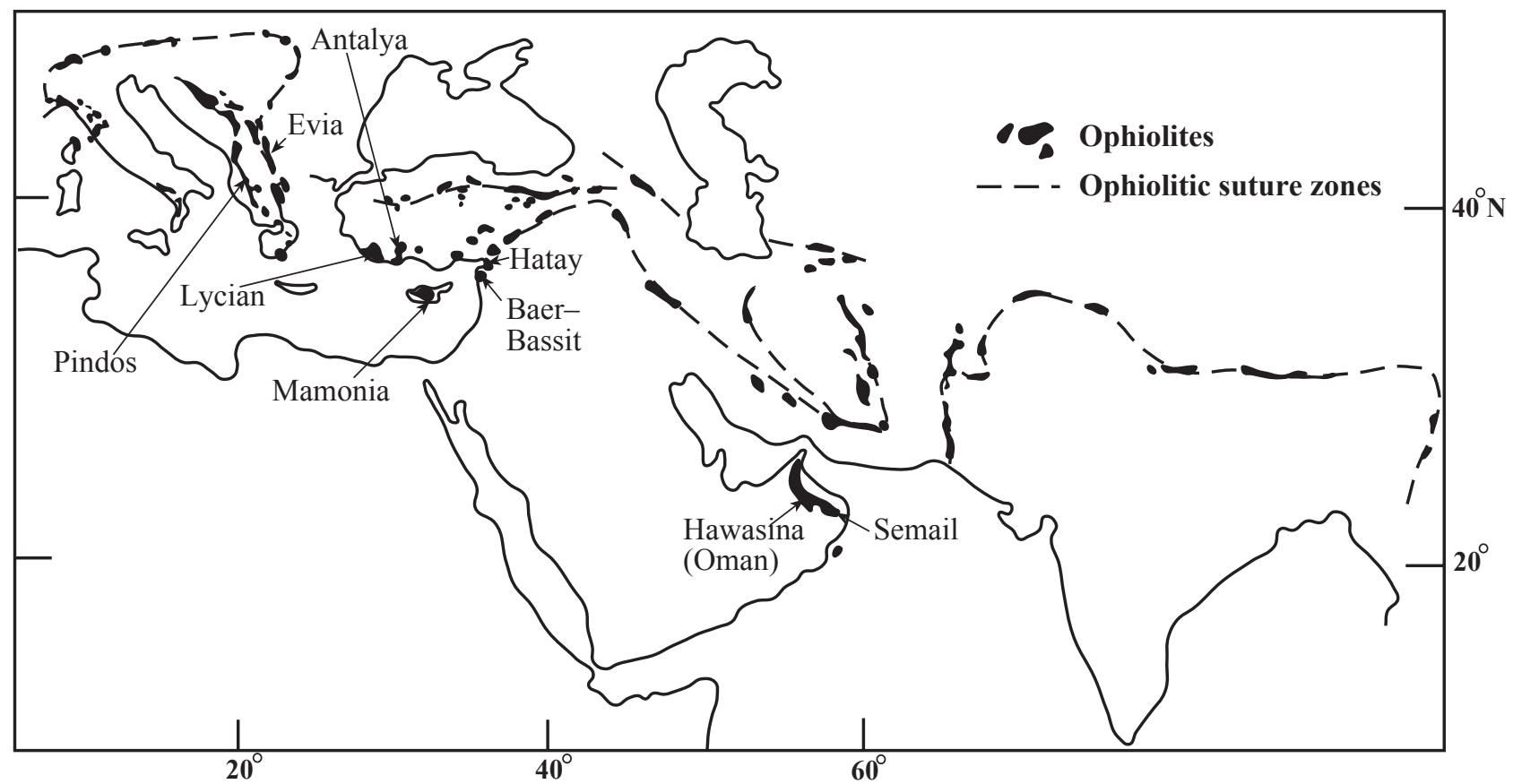

Figure 1. Setting of ophiolitic suture zones extending from the Eastern Mediterranean to Oman. Modified after Lippard, Shelton \& Gass (1986). Note the location of Baer-Bassit.

sedimentary and volcanic rocks discussed here are preserved as melange and broken formation. A 'melange' is a purely descriptive (non-genetic) field term for a pervasively mixed unit, irrespective of whether it was formed by tectonic or sedimentary processes, or both. A 'broken formation' preserves a disrupted but still recognizable original stratigraphy that is, however, more internally disrupted than that of thrust sheets (American Geological Institute, 1961). Melange blocks or dismembered thrust sheets in the BaerBassit region are in tectonic contact with each other and no contemporaneous sedimentary matrix is present (that is, the melange is not an 'olistostrome'). In places, the Baer-Bassit Melange is tectonically interleaved with slices of ophiolitic rocks, as seen in the Bassit Massif in the west (Figs 2, 3).

Within the Baer-Bassit Melange, local stratigraphic successions can be measured within individual blocks or broken formation, but no complete succession is present in any one geographic area, or tectonic unit. Successions within individual units were initially dated using calcareous fossils, mainly planktonic and benthic foraminifera (Delaune-Mayère \& Saint-Marc, 1979/80). During the present project the age resolution was improved using radiolarians extracted from siliceous facies (Al-Riyami et al. 2000; Al-Riyami, Danelian \& Robertson, in press).

Available age data show that successions within the Baer-Bassit Melange formed from Late Triassic to Late Cretaceous (Cenomanian) time in a deep-marine setting. During Middle Maastrichtian time, the sedimentary and volcanic successions were detached from their substratum and emplaced southwards onto the Arabian margin, which then formed part of a regionally submerged carbonate platform (Kazmin \& Kulakov, 1968; Al-Maleh et al. 1992). The emplaced units were briefly exposed, then transgressed by shallow-water carbonates during Late Maastrichtian time. Deeper water carbonate deposition over the allochthon resumed during Palaeocene-Eocene time and was followed by shallower water carbonate deposition in Early Oligocene time, prior to a regional cessation of deposition which persisted until Early Miocene time (Krasheninnikov, 1994). The hiatus may relate to closure of the South-Tethys in this region. Related compression resulted in open folding and faulting of the Baer-Bassit Melange and ophiolite, but no further regional-scale thrusting took place after latest Cretaceous time. However, the region was dissected by mainly NE-SW-trending strike-slip faults in Neogene time (Al-Riyami et al. 2000). The present exposure pattern (Fig. 8a) thus mainly results from a combination of Late Cretaceous tectonic emplacement and Neogene strike-slip. The overall tectonic evolution of the Baer-Bassit region is currently envisaged as shown in Figure 4 (Al-Riyami et al. 2000).

\section{Lithostratigraphy}

We have chosen not to set up a formal stratigraphy based on local names during this study, in view of the highly dismembered and variable state of successions within the Baer-Bassit Melange. However, where distinctive units were named in the past (DelauneMayère, 1984) we retain these as informal units. In addition to detailed mapping throughout the Baer- 


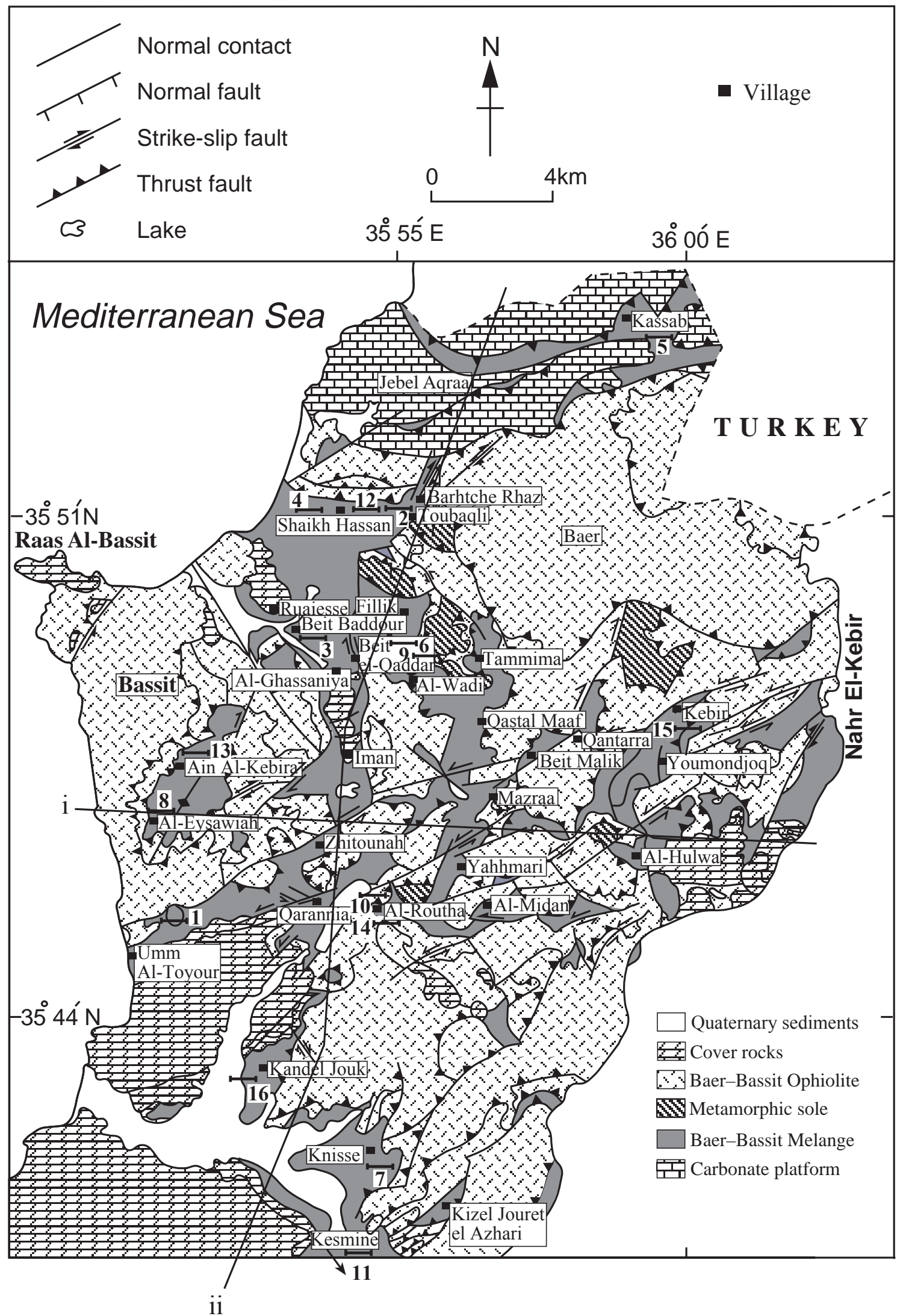

Figure 2. Geological map and sections of Baer-Bassit region, northern Syria. Simplified geological map of the Baer-Bassit region, northern Syria, showing the outcrops of the Baer-Bassit Melange discussed in the text. Map based on Kazmin \& Kulakov (1968), as modified by Al-Riyami et al. (2000). 
Bassit region (e.g. Fig. 5), we measured 16 detailed logs in sedimentary and volcanic successions, as shown in Figure 6. In general, two contrasting lithological assemblages are present. One comprises predominantly sedimentary rocks, including redeposited neritic carbonates and quartzose sandstones, of Late Triassic-Late Cretaceous age. The other mainly comprises alkaline volcanic and intrusive rocks, pelagic carbonates and radiolarian sediments, exhibiting a similar age range.

\section{3.a. Late Triassic lithofacies}

The following main lithofacies are present:

Limestone conglomerates. Large blocks (tens of metres in scale) of calcite-cemented, Late Triassic carbonates include coarse-grained limestones (calcirudites) that usually stratigraphically underlie calcarenite or fine-grained limestone (e.g. at Shaikh Hassan; Fig. 6, log 4). Individual units range from nearly massive to well-stratified (beds $15-30 \mathrm{~cm}$ thick) and contain coral fragments, bivalves, gastropods, ooids, peloids, faecal pellets, calcareous algae, benthic foraminifera, echinoids and intraclasts.

Calcarenites. Calcarenites, of Late Triassic age, usually occur as scattered, sheared and folded blocks $(2-10 \mathrm{~m}$ in size) of grey calcarenite within the melange, as seen in the west (e.g. at Al-Wadi and Shaikh Hassan; Fig. 6, $\log$ 4; Fig. 7). Elsewhere, smaller blocks, exhibiting good way-up criteria comprise local successions ( $<5 \mathrm{~m}$ thick) of graded calcarenite (beds $<2 \mathrm{~m}$ thick), passing up into pelagic limestone (as near Al-Wadi; Fig. 2). Individual calcarenites exhibit grading, parallel and crosslamination, typical of calcareous turbidity current deposits (e.g. Beall \& Fischer, 1969; Tucker \& Wright, 1990). Although palaeocurrents are locally preserved, an apparently random orientation of blocks in the melange precludes useful analysis. The calcarenites contain redeposited shallow-water carbonate with coral, calcareous algae, rare weathered basic volcanic clasts and echinoderm fragments (with calcite overgrowths), as well as local chert of replacement origin. The calcarenites are moderately to well-sorted packstones dominated by ooids and peloids (up to $1 \mathrm{~mm}$ in size). They contain benthic foraminifera and other microfossils including Diplopora sp., Ophalmidium sp., Miliolidae, Ammodiscidae, Nodosaria sp., Duostominidae, Endothyranella sp., Glomospira sp., to which a Late Triassic (Norian) age was assigned by S. TsailaMonopolis (pers. comm., 1998).

Fine-grained limestone. Pelagic limestsones (up to $70 \mathrm{~m}$ thick), containing the bivalve Halobia (DelauneMayère \& Saint-Marc, 1979/80), represent the stratigraphically lowest facies preserved in many of the blocks and dismembered thrust sheets (e.g. near Umm Al-Toyour, Youmondjoq and Shaikh Hassan villages; Figs 2, 8b). In the largest outcrop (near Umm Al-
Toyour; Fig. 6, $\log 1$ ) white pelagic limestone (beds $10 \mathrm{~cm}-1 \mathrm{~m}$ thick) is locally nodular with Halobia shell fragments. There are occasional argillaceous partings rich in finely divided plant fragments. In thin-section, common Halobia shell fragments and calcified radiolarians (up to $40 \%$ by volume) are present, together with scattered angular quartz grains.

There are several local facies variants. First, blocks $\left(10-20 \mathrm{~m}^{2)}\right.$ of varicoloured white, pink or purple-red pelagic limestones (e.g. near Al-Wadi village, Fig. 2) contain well-sorted, calcified radiolarian tests and finely disseminated, fine-grained iron oxide. Secondly, grey micritic limestones (beds $20 \mathrm{~cm}-1 \mathrm{~m}$ ) are interbedded with limestone conglomerates near the local stratigraphic base of individual blocks (e.g. at Shaikh Hassan; Fig. 2).

Bedded radiolarian cherts. In most outcrops, primary bedding within common red ribbon radiolarites is deformed by pressure solution to create irregular stylolites (e.g. near Umm Al-Toyour; Fig. 2). Chert beds in the upper part of the Halobia limestone succession were dated as Late Triassic (Middle-Late Carnian) using radiolarians (Al-Riyami, Danelian \& Robertson, in press). In one well-exposed (but stratigraphically inverted) succession at Toubaqli (Fig. 2; Fig. 6, $\log 2$ ) silicified red limestones (beds $c .10-30 \mathrm{~cm}$ thick) are depositionally overlain by red chert $(c .50 \mathrm{~m}$ thick). Individual radiolarian chert beds range in thickness from 3-4 cm thick and are interbedded with shale or mudstone. The Late Triassic radiolarian cherts contain numerous radiolaria set in a reddish, clay-rich, siliceous, or haematitic matrix, with minor calcium carbonate. In addition, rounded to sub-angular grains of recrystallized microspar are locally present. Additional bedded chert successions are exposed near Shaikh Hassan and near Kassab (in Toubaqli village and also near Barhtche Rhaz village; Fig. 2).

Interpretation. The lowest preserved sedimentary rocks, of Late Triassic age, record background deposition in an open-marine setting in which radiolarians flourished, giving rise, after diagenesis, to cherts and shales. Carbonate was redeposited into this setting from a shallow-water carbonate platform, assumed to have formed along the Arabian continental margin to the south. A distinct origin from a separate off-margin carbonate platform cannot be entirely ruled out from the evidence of the Late Triassic sediments. However, a setting adjacent to the Arabian margin is suggested by a comparison with Cretaceous sediments in the same area which include quartzose sandstones (see Section 3.c). The Late Triassic limestone conglomerates accumulated as debris flows in a relatively proximal base-of-slope depositional setting, interbedded with calciturbidites and peri-platform ooze. Since pelagic carbonates are interbedded with coarse, thickbedded redeposited carbonates, a relatively proximal depositional setting is inferred, marked by a relatively shallow carbonate compensation depth (CCD). 

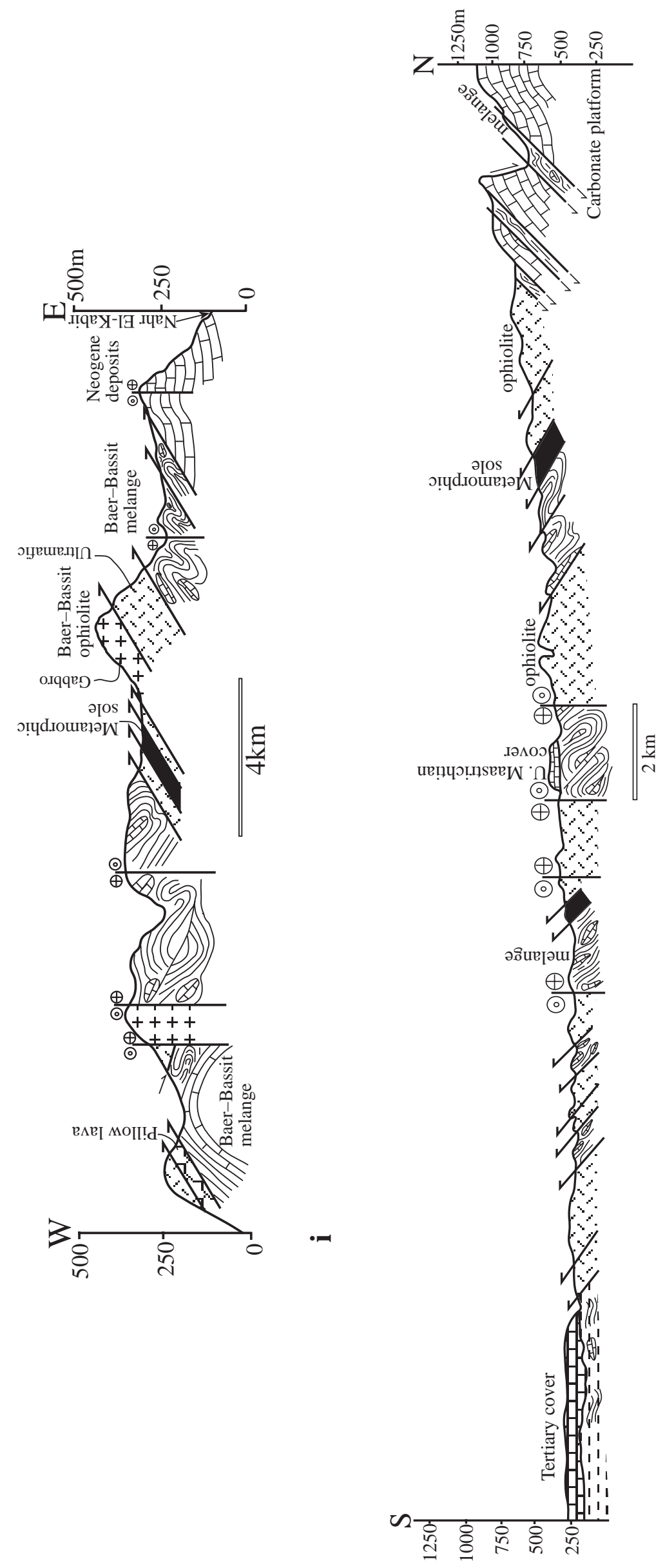

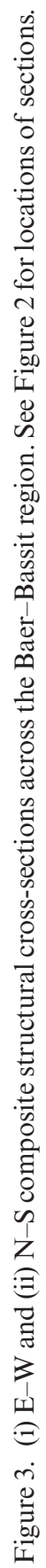


However, more proximal slope and platform units are not exposed, presumably because they are concealed beneath the allochthon further north. Overall, carbonate input waned with time, allowing the accumulation of thick (up to $50 \mathrm{~m}$ ) relatively homogeneous radiolarian ooze, with only minor input of redeposited carbonate that was extensively silicified during diagenesis.

\section{3.b. Jurassic lithofacies}

Successions of dated (and inferred) Early-Middle Jurassic age are restricted to mainly thinly bedded facies, preserved as fragmentary deformed successions within individual tectonic blocks or broken formation. Lithofacies are as follows:

Radiolarian cherts and shales. Relatively intact Upper Triassic successions locally pass upwards through a thin interval of red-grey-green marls into calcareous claystones, pinkish shales and radiolarian chert, up to tens of metres thick (Fig. 5, logs 1-3). These sediments are locally interbedded with siliceous limestone and rare thin-bedded sandstones. Wellexposed successions are seen in the Tammima, Shaikh Hassan, Beit Baddour, Kassab and Mazraa areas (Figs 2, 5, 6). Near Tammima (Fig. 2), a radiolarian succession is depositionally intercalated with alkaline volcanic rocks and intrusive rocks (Parrot, 1974a,b). The radiolarites are typical Tethyan ribbon cherts, comprising $>90 \%$ silica in beds, $5-10 \mathrm{~cm}$ thick. Most cherts are massive and granular, or show fine parallel lamination. Diagenetic nodularity is locally developed. In general, the red cherts contain densely packed, moderately to well-preserved radiolarian tests. Densely meshed radiolarian tests tend to be well preserved, whereas open-structured tests are infilled with, or replaced by, chalcedonic quartz. The radiolarian tests, together with numerous spines, are set in a brown, to yellowish brown, translucent matrix of ferruginous oxide, silica and clay.

Red ribbon chert ( $8 \mathrm{~m}$ thick) from Beit Baddour (Fig. 6, $\log 3$ ) was dated as Middle Jurassic (late Bajocianmiddle Bathonian) using radiolarians. In addition, at Kassab (Fig. 6, $\log 5$ ), a $10 \mathrm{~m}$ thick succession of red ribbon chert (beds $2-10 \mathrm{~cm}$ thick) was dated as Middle-Late Jurassic (Bajocian to Late Kimmeridgian/ Early Tithonian). Also, radiolarites from Shaikh Hassan in the southwest (Fig. 6, $\log 4$ ) indicate a Middle Jurassic (Bajocian to Late Bathonian/Early Callovian) age (Al-Riyami, Danelian \& Robertson, in press).

Fine-grained siliceous limestone. Thin-bedded $(5-10 \mathrm{~cm})$, white, siliceous pelagic limestone, intercalated with radiolarian chert, exhibits planar lamination and very small-scale cross lamination. These sediments are mainly composed of silica-filled radiolarian tests set in a fine calcareous matrix. Manganese oxy-hydroxide concretions and segregations are locally well developed (e.g. northwest of Beit El-Qaddar village; Fig. 5). The white interbeds were dated as
mid-Jurassic in age (Bajocian) using radiolarians from the interbedded ribbon cherts (Al-Riyami, Danelian \& Robertson, in press). In thin-section, the siliceous pelagic limestones are packstones rich in angular poorly sorted calcareous peloids $(0.1-0.5 \mathrm{~mm}$ in size), forming c. $40 \%$ of the rock, together with moderately to well-sorted radiolarian tests and moderately wellrounded quartz grains. Finely crystalline diagenetic chert and coarser siliceous cement has replaced much of the primary carbonate. Disseminated iron and manganese oxy-hydroxides are commonly present. On the road to Al-Routha village (Fig. 2), calcareous siltstones of inferred Early Jurassic age (DelauneMayère \& Saint-Marc, 1979/80) were found to comprise diagenetically silicified, fine-grained limestones, interbedded with dark red thinly bedded chert.

Claystone and siliceous claystone. The Jurassic succession is locally dominated by claystones, up to c. $12 \mathrm{~m}$ thick. Thin beds and partings of reddish to light green, fine-grained claystone are mainly composed of microcrystalline quartz $(50-70 \%)$ and clay minerals. Dark brown, well-lithified, horizons are intercalated with thin partings rich in microcrystalline calcite. Some claystones locally contain thin $(2-5 \mathrm{~cm})$ layers of red to green shale or claystone (e.g. Shaikh Hassan and Kandel Jouk areas (Fig. 6; e.g. $\operatorname{logs} 4,16$ ). Elsewhere, deep pink claystone is more siliceous, being rich in microcrystalline quartz. In places, ribbon cherts and shales include scattered thin beds of siliceous limestone rich in radiolarians and an occasional thick bed of argillaceous limestone $(1 \mathrm{~m})$ (e.g. near Shaikh Hassan; Figs 2, 5). The claystones are dated by an association with interbedded radiolarites (see above).

In addition, occasional intervals of pink and creamcoloured medium-grained, granular-textured sedimentary rock, forming beds up to several metres thick, were found to be composed of a mixture of microcrystalline quartz and calcite in thin-section. These sediments originated as redeposited limestones but later underwent diagenetic silicification and recrystallization.

Calcarenites. Local occurrences of fossiliferous, occasionally bioturbated grey to brown, packstones (beds $40 \mathrm{~cm}-2 \mathrm{~m}$ thick) contain peloids, shell fragments, oncoids, microbial carbonate, benthic foraminifera and gastropods, set in a microspar and iron-oxide cement. At Al-Midan (Fig. 2), the calcarenite contains gastropods, benthic foraminifera, ostracods and benthic foraminifera, including Thaumatoporella parvovesiculifera, Textulariidae, Valvulinidae, Pseudocyclamminalituus), also calcareous algae (Dacscladaceae), of inferred Late Jurassic age (K. Al-Riyami, unpub. $\mathrm{Ph} . \mathrm{D}$. thesis, Univ. Edinburgh, 2000). A layer of bioturbated light pink to white calcarenite-calcirudite near Beit El-Qaddar (Fig. 6, $\log$ 9), contains poorly sorted shell fragments, together with rounded to subrounded clasts of basic volcanic rocks (up to $15 \%$ by volume), carbonate lithoclasts and chert. Thin-section study revealed peloids, black basalt particles (includ- 
ing melilite crystals) and fragments of ostracods, bryozoans, corals, echinoderms, large foraminifera and recrystallized radiolaria. In some places, the calcarenites are interbedded with volcaniclastic sedimentary rocks (e.g. near Al-Midan village, Fig. 2).

Interpretation. The Jurassic time interval was characterized by deposition of siliceous radiolarian ooze and non-calcareous muds. Minor volumes of shallowwater carbonate were introduced, mainly as relatively thin-bedded calciturbidites and micrite derived from the adjacent carbonate platform. These sediments were extensively silicified during diagenesis and preserved as chert of replacement origin. Occasional interbeds of fine-grained carbonate may reflect gravity input of peri-platform ooze, rather than sea-floor preservation of calcium carbonate. Local intercalations of volcaniclastic gravity deposits during Late Jurassic time point to the existence of alkaline volcanism in the vicinity (see Section 5.d). However, tuff derived from subaerial fallout was not detected, suggesting that the volcanism was subaqueous.

\section{3.c. Cretaceous lithofacies}

During Berriasian time sedimentation changed from mainly siliceous to calcareous, with deposition of fine, medium- and coarse-grained carbonates. These are interbedded with argillaceous and siliceous deposits, as follows:

Fine-grained limestone. Hemipelagic carbonates are developed mainly as thin interbeds between other lithofacies. In the southwest, near Ain Al-Kebira and Al-Routha (Fig. 6, logs 13, 14) hemipelagic carbonates, locally interbedded with radiolarian chert, have yielded planktonic foraminifera including Hedbergella sp., Sytomiosphaera sp. , Heterohelix sp. and Pithonella ovalis of Berriasian age (S. Tsaila-Monopolis, pers. comm., 1998). In addition, Delaune-Mayère \& SaintMarc (1979/80) identified Calpionellitis darderi and Calpionellopsis sp., of inferred Valanginian age. Hemipelagic carbonates with replacement chert from Al-Ghassaniya village (Fig. 2) contain Cenomanian planktonic foraminifera (Delaune-Mayère \& SaintMarc, 1979/80).

In addition, a unit of massive, brown ferruginous wackestone (up to $12 \mathrm{~m}$ thick), exposed near Kesmine village (Fig. 6, $\log 11$ ), above red radiolarian chert, contains rounded to sub-rounded peloids and sparse sub-angular quartz grains $(<10 \%)$ set in a microspar cement. This is considered mainly as the fine fraction of coarser redeposited carbonate.

Calcarenite. Packstones (3 $\mathrm{m}$ thick), rich in replacement chert, from near Beit El-Qaddar (Fig. 6, $\log 6$ ) exhibit grading, micro-cross-lamination and flute marks. The packstone contains well-sorted, to poorly sorted, moderately well-rounded peloids, ooids, ostracods, bivalves and echinoderm spines (with syntaxial overgrowths). A few grains of chlorite, glauconite and angular quartz are set in a calcite spar cement. Higher in the succession, thinner-bedded packstones contain poorly sorted ooids, echinoderm spines, bivalve fragments, bryozoans, grapestone aggregates and benthic foraminifera. The calcarenites are overlain by calcareous mudstone.

The above succession contains benthic foraminifera (e.g. Gavellinella sp., Orbitolina sp., Nautiloculina sp. and Miliolina sp.), indicative of a BerriasianValanginian age. Intraclasts also contain Calpionellidae. Elsewhere, at Ruaiesse and Beit El-Qaddar (Fig. $6, \log 9$ ), nearly massive packstones, exposed as large detached blocks (3-5) are strongly bioclastic and include fragments of gastropods, microbial carbonate, shell fragments, radiolaria, ostracods, bryozoa, red algae, benthic foraminifera, pellets and coral, cemented by several generations of calcite spar. Benthic foraminifera are again indicative of an Early Cretaceous age (K. Al-Riyami, unpub. Ph.D. thesis, Univ. Edinburgh, 2000). In addition, in the south, near Knisse village (Fig. 6, $\log 7$ ), calcarenites interbedded with red chert exhibit a fibrous aragonite cement, mainly surrounding pellets and again contain benthic foraminifera of Early Cretaceous age (K. Al-Riyami, unpub. Ph.D. thesis, Univ. Edinburgh, 2000).

The redeposited carbonates range at least up to Cenomanian in age. For example, calcarenites from Al-Routha, east of Shaikh Hassan (Fig. 6, log 14) contain the benthic foraminifera Praealveolina, Orbitolinidae, Charentia sp., Murgeina apula, Melobesiodeae, Nodosariidae and Orbitolinidae (S. Tsaila-Monopolis, pers. comm., 1998).

Conglomerates. Cretaceous conglomerates, both clast- and matrix-supported, are exposed as relatively intact successions (e.g. Shaikh Hassan, section a; Fig. 6, $\log$ 12; Ain Al-Kebira; Fig. 6, $\log 13$; Fig. 8c) and as disrupted blocks in the melange (e.g. Beit Baddour; Fig. 2). The main clasts present are calcarenite and wackestone (up to $40 \mathrm{~cm}$ in size), black chert, as well as rarer clasts of quartzite, quartzarenite, volcanic and volcaniclastic rocks, pink and grey wackestone and chert. A wide variety of shallow-water bioclasts are present, including microbial carbonate, coral, echinoids and shell fragments, together with chert, sandstone, siltstone, dolomite, and both igneous and metamorphic rock fragments.

In one area (near Ain Al-Kebira and Al-Eysawiah; Fig. 6, $\log 8$ ) the Barremian-Aptian succession begins with massive, white, clast-supported conglomerate, with common replacement chert, then grades into chalky limestone and pelagic carbonate rich in planktonic foraminifera. Lithoclasts include radiolarian packstone inter-laminated with radiolarian chert and well-laminated dark organic-rich wackestones. Some of the siliceous clasts were lithified before being incorporated into the conglomerate. Locally, these conglomerates show clast imbrication indicating flow to the north (within a block). In a second area (near Al- 


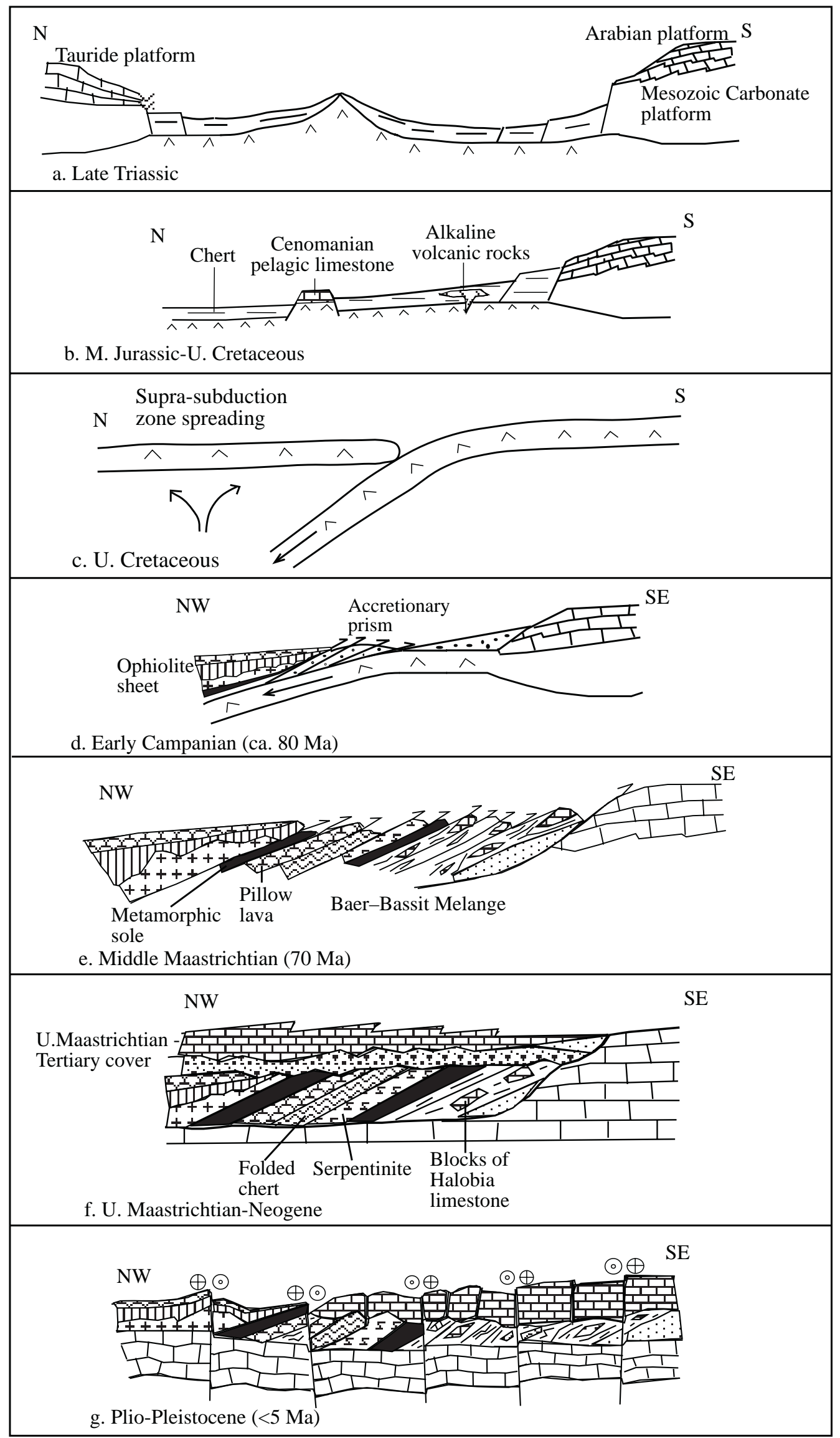

Figure 4. Summary of the tectonic evolution of the Baer-Bassit area, northern Syria. After Al-Riyami et al. (2000). 


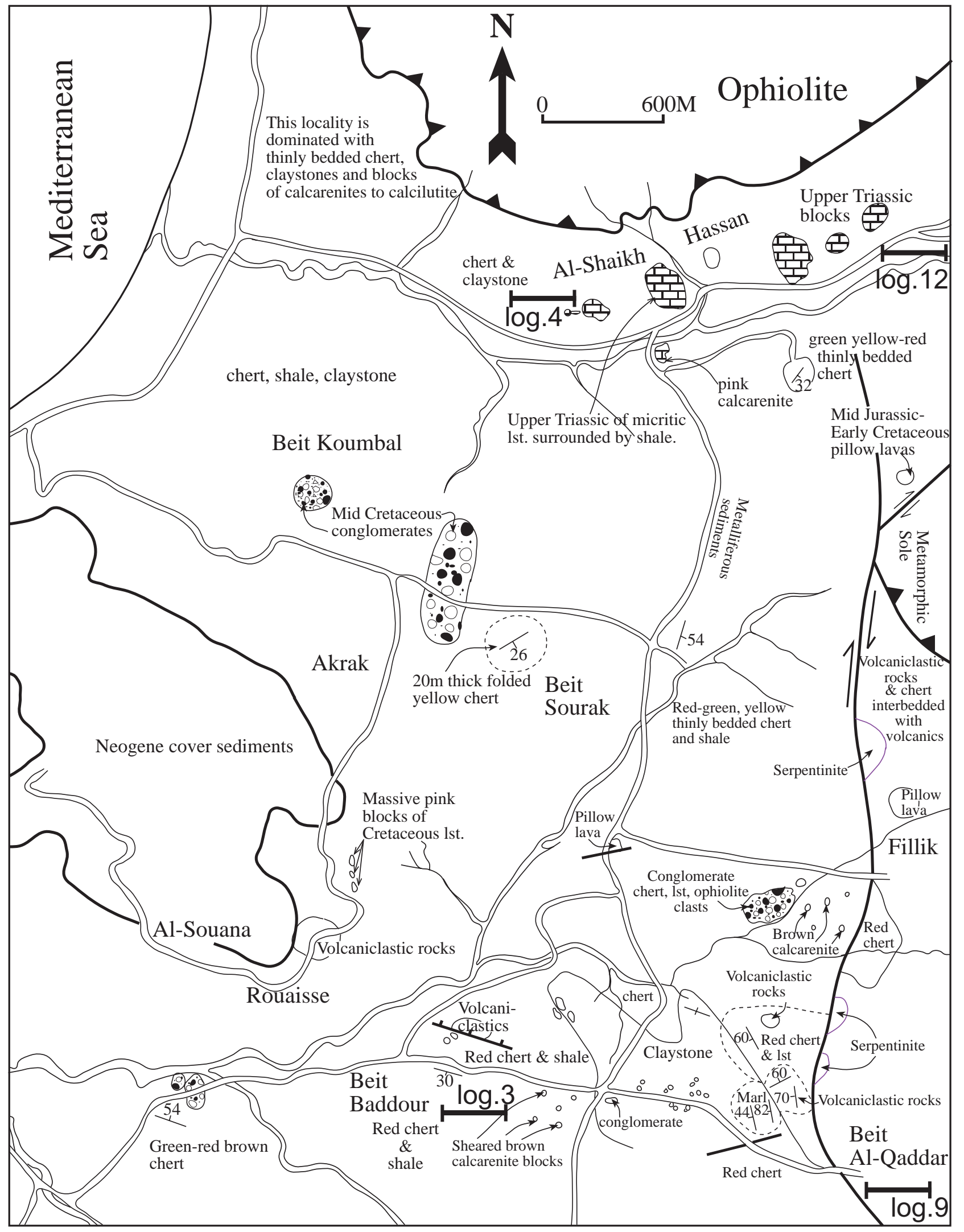

Figure 5. Detailed geological map of the northwestern part of the Baer-Bassit region showing the distibution of the melange and the location of places mentioned in the text. See text for explanation. Logs 3, 4, 9, and 12 are indicated (see Fig. 6). 


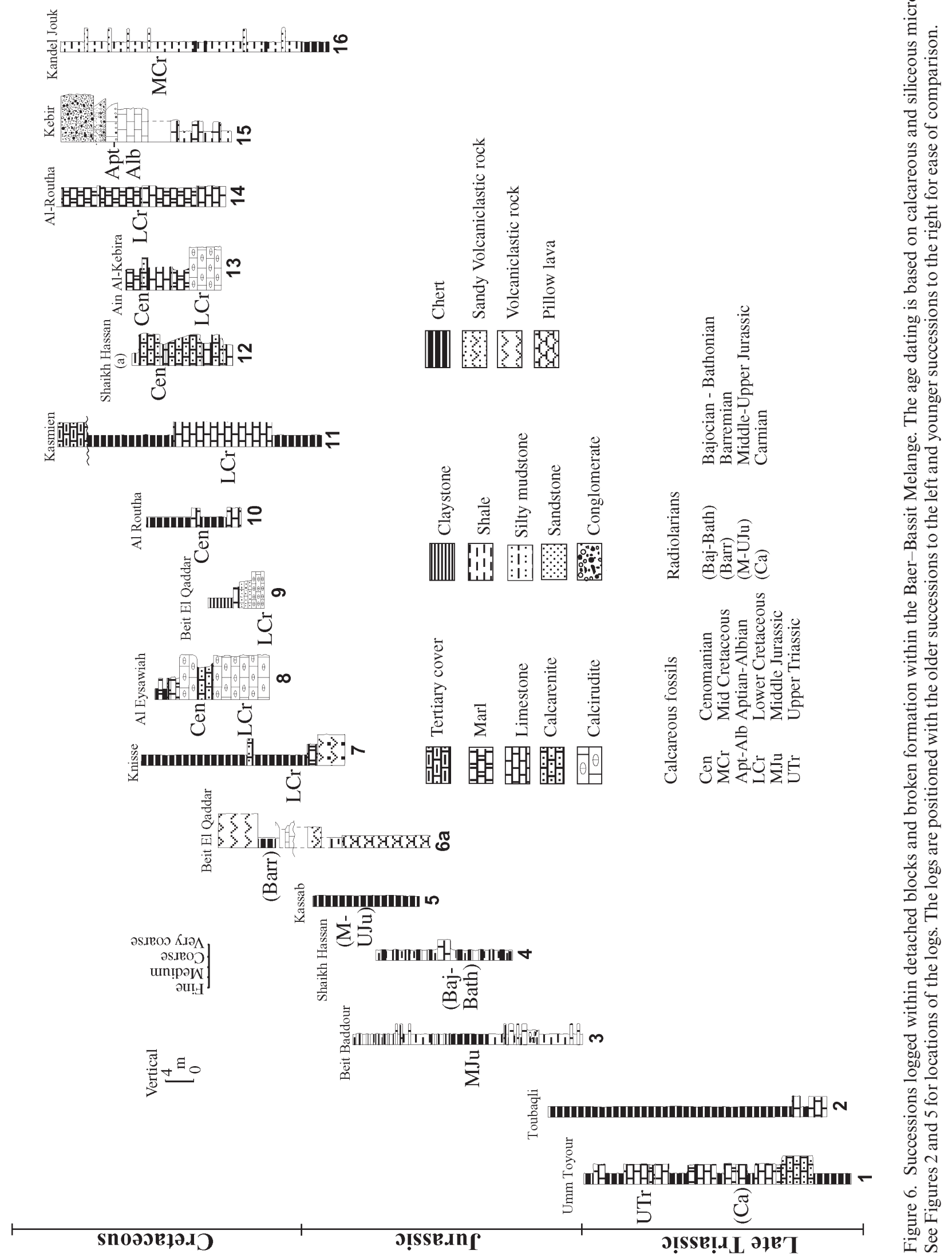



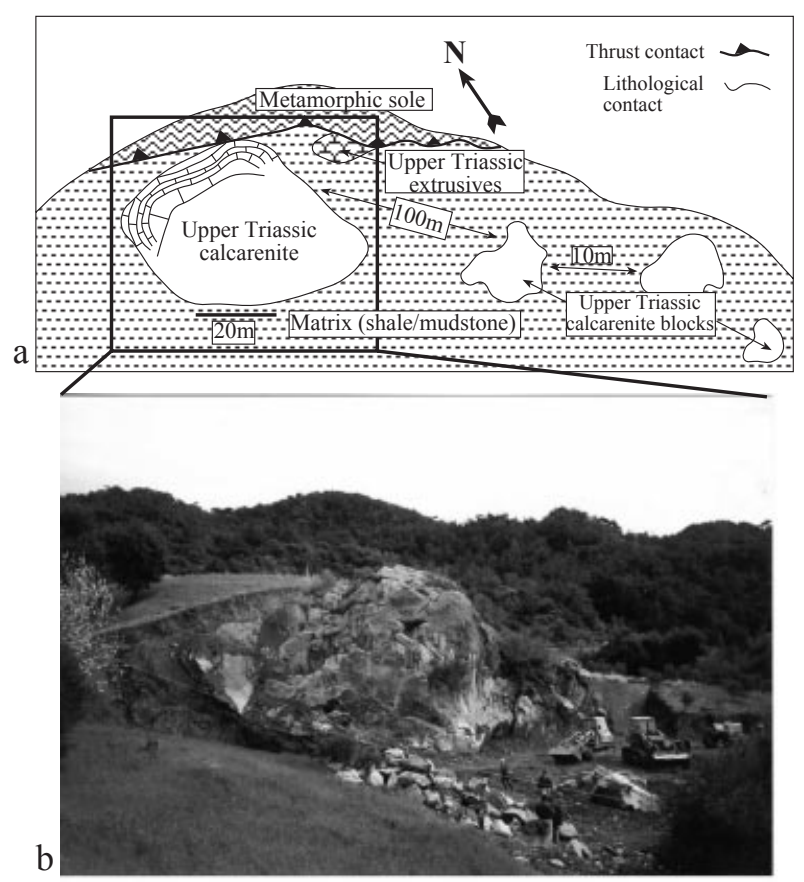

Figure 7. Sketch section and photograph of Upper Triassic calcarenite blocks set in a shaly matrix and locally overlain by the metamorphic sole of the ophiolite. Near Al-Wadi village (Fig. 2).

Eysawiah), the succession begins with thick-bedded $(2 \mathrm{~m})$, poorly sorted, matrix-supported intraformational conglomerate $(7 \mathrm{~m})$, with randomly distributed angular to sub-rounded clasts $(0.5-12 \mathrm{~cm}$ in size). This is overlain by calcarenite $(80 \mathrm{~cm})$, then by several thick beds of matrix-supported conglomerate containing many chert and packstone clasts $(<3 \mathrm{~cm}$ in size). Marly limestones and claystones follow above.

The youngest known sediments in the melange, of inferred Cenomanian-Turonian age, are dominantly conglomerates and calcarenites. For example, at AlGhassaniya (Fig. 2) the exposed succession begins with matrix-supported, moderately sorted conglomerate $(40 \mathrm{~cm}$ thick). Clasts are angular to sub-rounded and include carbonate rocks, chert and igneous rock fragments (2-4 cm in size). Overlying matrix-supported conglomerates were found to contain $50 \%$ carbonate, $30 \%$ chert and $20 \%$ igneous clasts within a $2 \mathrm{~m}^{2}$ area based on clast counting (335 clasts). Similar Cenomanian-Turonian matrix-supported conglomerates are exposed in the western part of the area (e.g. near Beit Baddour and Shaikh Hassan; Fig. 2), where beds reach 3-4 $\mathrm{m}$ in thickness.

Claystone. Yellow to green claystones (1.3 m thick) overlie carbonate conglomerates (1 m thick) near Ain Al-Kebira, Al-Eysawiah and Beit El-Qaddar; Fig. 6, $\operatorname{logs} 6,8,13)$. Individual claystone interbeds $(2-20 \mathrm{~cm}$ thick) are interbedded with well-laminated green mudstone and laminated, yellow to green, silty wackestone $(<10 \mathrm{~cm}$ thick), including scattered concre- tions of replacement chert. This succession was dated by Delaune-Mayère \& Saint-Marc (1979/80) as Cenomanian, based on the presence of the foraminifera Hedbergella sp., Gavelinellidae, Heterohelix, Pithonella ovalis and P. spaerica.

Sandy limestone. A distinctive interval, up to $40 \mathrm{~m}$ thick, mainly composed of sandy limestone, was included within the 'Kebir Formation' of DelauneMayère \& Saint-Marc (1979/80). This is mainly exposed in the east, from Kebir to the north to AlHulwa village in the southeast (Fig. 2). Additional small outcrops were identified in the west (e.g. near Youmondjoq, Fig. 2). The Kebir formation as a whole is relatively resistant to erosion and locally forms cliffs up to $30 \mathrm{~m}$ high. The succession is thickest $(30 \mathrm{~m})$ near Qantarra village (Fig. 2) where it comprises the following succession: (1) quartzose sandstone (beds $<20 \mathrm{~cm}$ thick), including thick-bedded sandy calcarenite with scattered concretions and lenticles of replacement chert; (2) an interval (15 m thick) of sandy calcarenite (beds 40-50 cm thick); (3) overlying calcarenites and calcirudites with (up to gravel-sized) clasts of quartzite, chert and bioclasts (including coral fragments). The Kebir formation was dated as Late AptianMiddle Albian by Delaune-Mayère \& Saint-Marc (1979/80), based on the presence of Nautiloculina $\mathrm{cf}$. Bronnimani, Orbitolina cf. parva, Lituolidae, Miliolidae, Textulariidae, Pseudocyclammina sp., Haplophragmoides sp., Sabaudia sp., Acicularia cf.clapei, Bacinella irregularis, Kymalithon aggregatum, Heterohelix, Hedbergella sp., Pithonella ovalis and ostracods. The upper part of the succession was dated as Upper Albian-Middle Cenomanian, based on Orbitolina $\mathrm{cf}$. conica, Nezzarata simplex, Lithophyllum shebae, Acicularia sp., Textulariidae, ostracods and bryozoans.

The facies of the sandy limestones varies considerably. Massive brown calcareous sandstone, exposed near Al-Hulwa village (Fig. 2), is a sub-litharenite (calcareous sandstone), with microcrystalline quartz and abundant micritic carbonate rock fragments, set in a calcite spar cement. Aragonitic shell fragments are common, together with angular grains of chert, chlorite, plagioclase and rare olivine. Some of the quartz grains show rare quartz overgrowths. Most grains are moderately to poorly sorted and angular to subrounded. Elsewhere, at Beit Malik (Fig. 2), exposed lithofacies range from calcarenite, to sandy calcarenite, to calcareous sandstone and sandstone (in layers $<30 \mathrm{~cm}$ thick). Quartz grains, mostly monocrystalline, are poorly to moderately sorted, sub-angular to subrounded. Limestone fragments and a few silicified grains (chert) are present, within a calcite spar cement. In some areas calcareous sandstones are interbedded with calcareous mudstone, with shell and fossil fragments, pellets, scattered angular quartz, chert grains and radiolarians (replaced by calcite).

Quartzose sandstone. There is a compositional spectrum from sandy limestone to orthoquartzite 

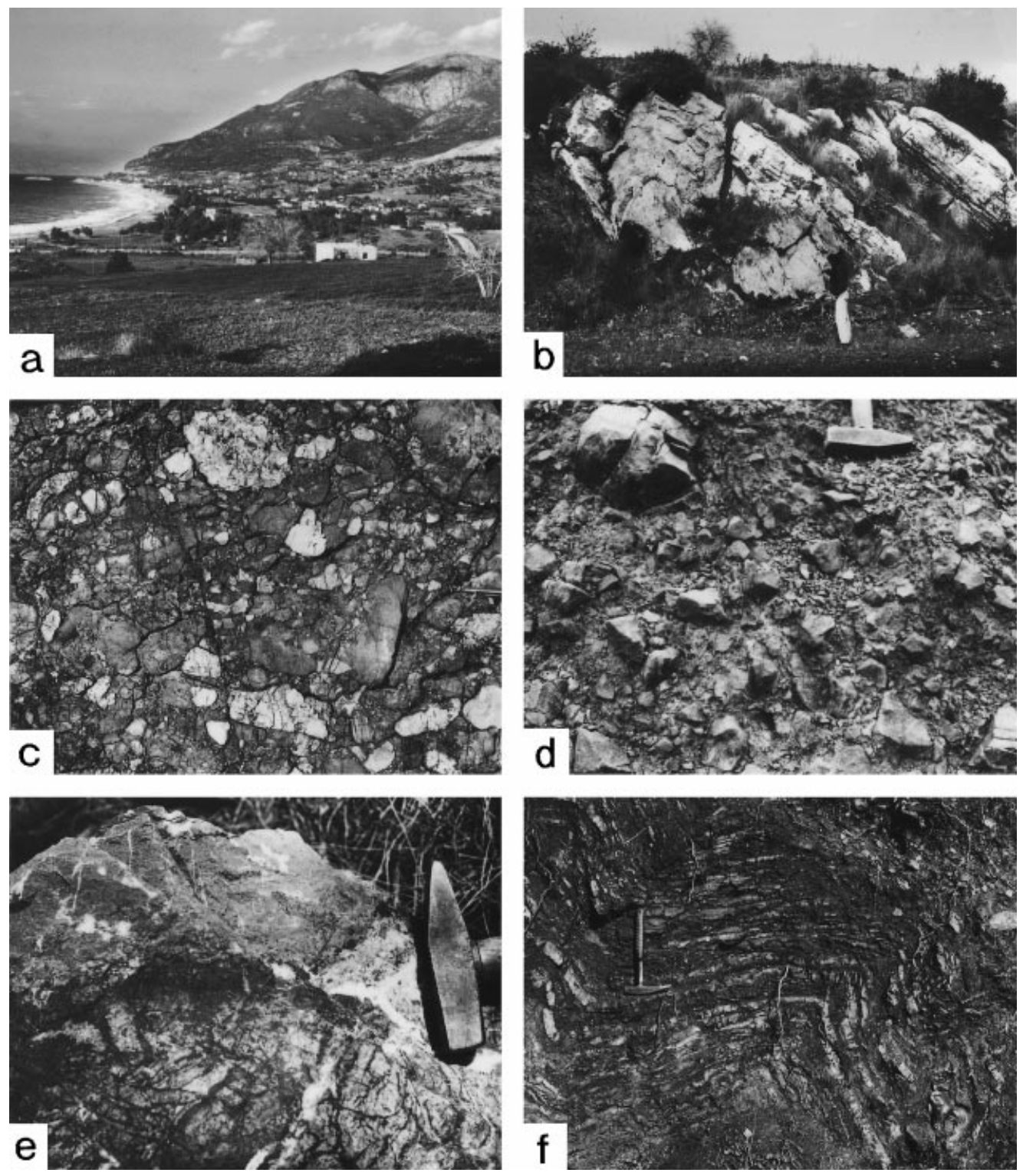

Figure 8. Field photographs of lithologies of the Baer-Bassit Melange. (a) General view over the Baer-Bassit Melange towards Jebel Aqraa carbonate platform; (b) Late Triassic limestone, near Umm Al-Toyour; (c) Albian chanellized conglomerate; Ain Al-Kebira; (d) mid-Jurassic-Early Cretaceous pillow breccia; near Qastal Maaf; (e) Crust of manganese oxide (dark, lower) overlain by reddish pelagic carbonate (upper) of Cenomanian age; near Tamima; (f) Chevron-folded radiolarian cherts near Qastal Maaf, indicating typical style of deformation. Scale: Hammer head $=14 \mathrm{~cm}$ long; in (c), the largest clast is $25 \mathrm{~cm}$ long.

(quartzarenite) in the type area of the Kebir formation (near Kebir; Fig. 6, log 15). Elsewhere (e.g. Fig. 6, log 16), quartzose sandstones $(5-10 \mathrm{~cm}$ thick) are interbedded with shale dated as Middle Cretaceous (Delaune-Mayère \& Saint-Marc, 1979/80). Some of these sandstones exhibit grading and flute marks. Light green, fine- to medium-grained quartzarenite (beds $<5 \mathrm{~cm}$ thick) is intercalated with red shaly chert near Yahhmari village. This lithology includes well-sorted, angular to sub-angular quartz grains (with inclusions), scattered mica and chlorite grains, cemented by calcite spar. Elsewhere, in the Kandel Jouk area (Fig. 6, log 16) calcareous quartzarenite is interbedded with red shale and contains angular to sub-angular moderately sorted grains, including chert, mica, chlorite and rare plagioclase. Some quartz grains are replaced by calcite.

Eight samples were point counted (600-900 points). On $\mathrm{Q}: \mathrm{F}: \mathrm{L}$ triangular plots (quartz-feldspar-lithic grains) four samples plot in the pure quartz field, whereas the other four plot in the litharenite field (Fig. 9a).

Interpretation. Early Cretaceous (Berriasian) time was marked by a return to mainly calcareous sedimentation related to the adjacent Arabian carbonate platform. Many of the carbonate clasts were derived from a carbonate slope as well as from a neritic platform. 
Rare dark, organic-rich lithoclasts were possibly derived from the carbonate slope, within the oxygen minimum zone. A relatively proximal setting is indicated by the occurrence of limestone conglomerates, interpreted as channellized debris flows, together with calciturbidites and reworked peri-platform ooze. Deep-water conditions persisted, as shown by the presence of intercalations of siliceous shale and pelagic micrite. During Early Cretaceous time, redeposited shallow-water carbonate accumulated, coupled with localized input of quartzose sandstone, mainly during Late Aptian-Middle Albian time (but locally persisting until Cenomanian time). These sands are assumed to have their ultimate source in the Pan-African basement to the south. The quartzose sandstone is most abundant in the east of the area, whereas contemporaneous successions in the west are dominated by redeposited carbonate. The sands were perhaps fed from the platform to the basin through a localized submarine canyon system in the east.

\section{Geochemistry and mineralogy of shales}

To supplement previous mineralogical work by Delaune-Mayère (1983), 30 samples of mudstones and shales were subjected to whole-rock X-ray diffraction analysis. The samples were also treated with ethylene glycol and heated to $550^{\circ} \mathrm{C}$ to help identify clay minerals. Quartz is ubiquitous, whereas smectite is moderately abundant to abundant. Kaolinite is widely distributed, ranging from abundant to trace amounts. However, calcite is only rarely abundant in the samples studied. In addition, haematite is commonly present, to locally abundant. Muscovite, albite, gypsum and anhydrite are also present in some samples.

Fifteen samples of shale, collected from various parts of the overall Upper Triassic to Cretaceous successions, were chemically analysed for major and trace elements by X-ray fluorescence, following the method of Fitton et al. (1998) (Table 1). When plotted on the ternary $\mathrm{SiO}_{2}-\mathrm{Fe}_{2} \mathrm{O}_{3}-\mathrm{Al}_{2} \mathrm{O}_{3}$ diagram (Fig. 9b) the shales plots close to the $\mathrm{SiO}_{2}$ apex, with a spread towards $\mathrm{Al}_{2} \mathrm{O}_{3}$. The probable source constituents are terrigenous clay and biogenic silica. When the samples were normalized against average shale composition (Fig. 10), using the data of Gromet et al. (1984), shales from different parts of the succession were found to be compositionally similar. They exhibit a marked relative depletion of $\mathrm{Cr}$ and small depletions of $\mathrm{Ba}$, Th and $\mathrm{Rb}$; also, there is an enrichment of $\mathrm{Y}$. The relative depletion of $\mathrm{Ba}$ and $\mathrm{Rb}$ is consistent with a low feldspar content, as in the quartzose sandstones (Fig. 9a). In addition, when plotted on tectonic discrimination diagrams (Bhatia, 1983) the shale composition is suggestive of a former oceanic island arc or a continental arc setting that is assumed to lie within the Precambrian basement (K. Al-Riyami, unpub. Ph.D. thesis, Univ. Edinburgh, 2000).
Table 1. Representative geochemical analyses; typical shale from successions unrelated to volcanism

\begin{tabular}{lcccc}
\hline Sample no. & F2/L317 & F2/L4 & F2/11 & F2/15 \\
\hline $\mathrm{SiO}_{2}$ & 66.87 & 68.71 & 57.16 & 66.6 \\
$\mathrm{Al}_{2} \mathrm{O}_{3}$ & 14.63 & 11.94 & 14.41 & 12.73 \\
$\mathrm{Fe}_{2} \mathrm{O}_{3}$ & 7.49 & 7.6 & 8.61 & 5.04 \\
$\mathrm{MgO}$ & 1.46 & 1.95 & 2.43 & 1.3 \\
$\mathrm{CaO}$ & 0.43 & 1.74 & 4.71 & 3.83 \\
$\mathrm{Na}_{2} \mathrm{O}$ & 0.8 & 0.03 & 0.32 & 0.45 \\
$\mathrm{~K}_{2} \mathrm{O}$ & 1.563 & 1.636 & 1.911 & 1.156 \\
$\mathrm{TiO}_{2}$ & 0.832 & 0.765 & 1.075 & 0.795 \\
$\mathrm{MnO}$ & 0.022 & 0.015 & 0.09 & 0.115 \\
$\mathrm{P}_{2} \mathrm{O}_{5}$ & 0.124 & 0.049 & 0.132 & 0.107 \\
$\mathrm{LOI}$ & 5.24 & 5.34 & 8.65 & 7.37 \\
$\mathrm{Total}$ & 99.46 & 99.77 & 99.49 & 99.49 \\
& & & & \\
$\mathrm{Nb}$ & 19.4 & 19.6 & 26.9 & 21.3 \\
$\mathrm{Zr}$ & 137 & 114.4 & 163 & 149 \\
$\mathrm{Y}$ & 23.8 & 14.6 & 23.1 & 23.8 \\
$\mathrm{Sr}$ & 280.5 & 57.1 & 143.3 & 154.8 \\
$\mathrm{Rb}$ & 62 & 54.7 & 67 & 48.6 \\
$\mathrm{Th}$ & 5.1 & 3.5 & 4.7 & 5.2 \\
$\mathrm{~Pb}$ & 27.1 & 11.9 & 15 & 16.4 \\
$\mathrm{Zn}$ & 79.1 & 88.1 & 88.2 & 76.2 \\
$\mathrm{Cu}$ & 45.8 & 104.8 & 56 & 80.6 \\
$\mathrm{Ni}$ & 58.7 & 78 & 74.8 & 50.4 \\
$\mathrm{Cr}$ & 98.6 & 80.3 & 138.3 & 85.6 \\
$\mathrm{Ce}$ & 82.6 & 58.9 & 96.5 & 86.1 \\
$\mathrm{Nd}$ & 32 & 16.5 & 36.7 & 34.6 \\
$\mathrm{La}$ & 36.9 & 34.4 & 34.6 & 42.9 \\
$\mathrm{~V}$ & 123.6 & 114.2 & 128.8 & 117.7 \\
$\mathrm{Ba}$ & 269.9 & 116.9 & 152.1 & 99.7 \\
$\mathrm{Sc}$ & 15.8 & 9.1 & 20.9 & 12.5 \\
\hline
\end{tabular}

Major elements in weight $\%$ oxide; trace elements in parts per million. Method of Fitton et al. (1998). Loss on ignition values range from $2.62-7.6 \%$ in the basalts. The analyses were recalculated on a volatile-free basis before plotting on discrimination diagrams to avoid the effects of alteration and the local calcite amygdales. (See also Table 2.)

\section{Volcanic and volcaniclastic rocks}

Basic extrusive rocks of Late Triassic and Middle Jurassic-Early Cretaceous age occur as detached blocks and outcrops of broken formation within the Baer-Bassit Melange, associated with various sedimentary rocks (Fig. 11a, b), as detailed in the next sections.

\section{5.a. Late Triassic extrusive rocks}

Basic extrusive rocks, mainly pillow lavas, subordinate lava breccias (Fig. 8d) and rare hyaloclastite are exposed as intact units up to $25 \mathrm{~m}$ thick. In thinsection, the Upper Triassic extrusive rocks contain large phenocrysts of kaersutitic hornblende, sericitized plagioclase, titaniferous augite and opaque minerals, set in a groundmass of glass, now altered to zeolite, chlorite and epidote. In some areas the extrusive rocks are interbedded with hemipelagic limestone and ribbon radiolarite (e.g. near Al-Wadi village; Fig. 12a), but without sandstone or redeposited neritic limestone. These limestones contain Halobia sp. and were dated as Late Triassic in age (Parrot, 1974b; Delaune-Mayère \& Saint-Marc, 1979/80). Elsewhere, 


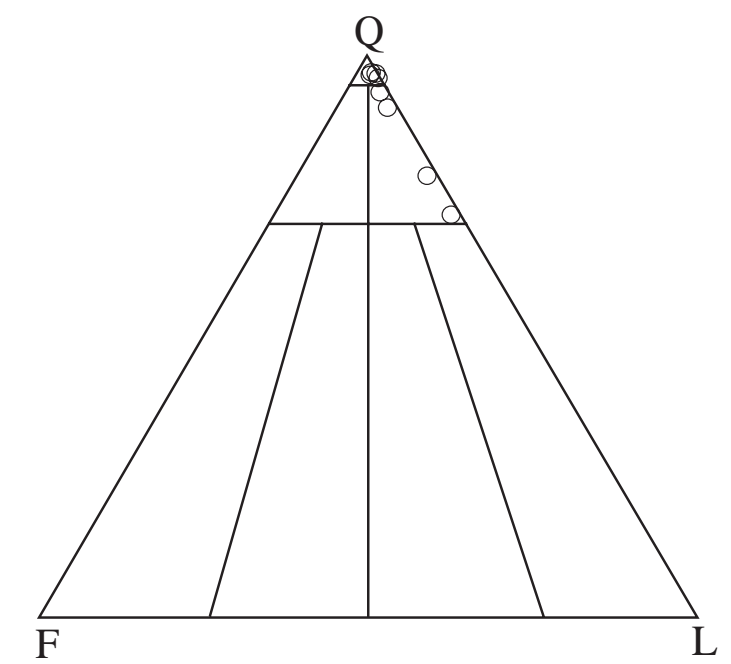

a

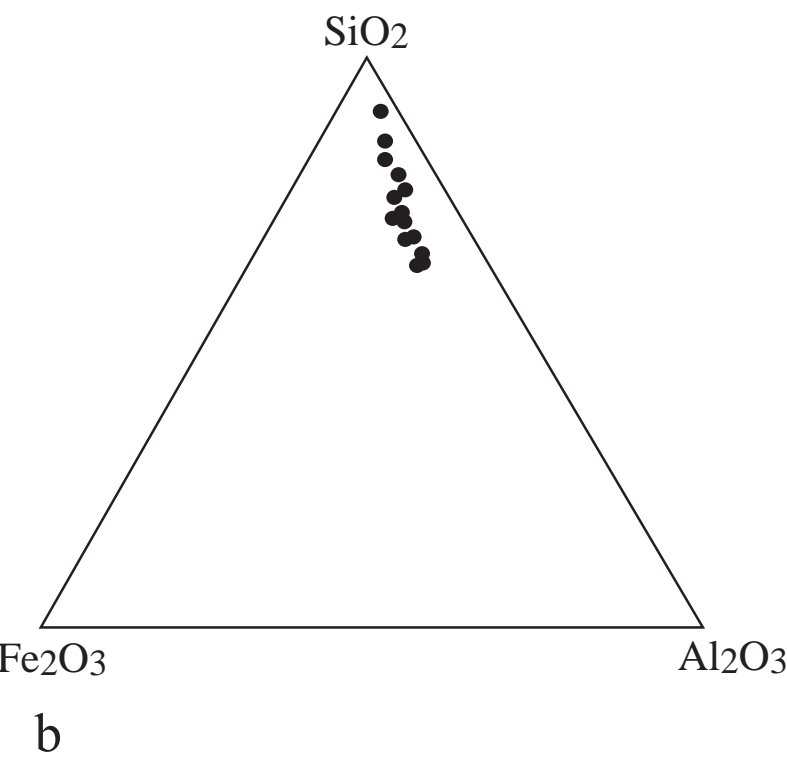

Figure 9. Composition of terrigenous-derived sedimentary rocks. (a) Triangular plot of quartzose sandstones from the Albian Kebir formation. Q - quartz, F - feldspar, L - lithic (rock fragments). See text for explanation. Note the very quartz-rich nature. (b) $\mathrm{SiO}_{2}-\mathrm{Fe}_{2} \mathrm{O}_{3}-\mathrm{Al}_{2} \mathrm{O}_{3}$ plot of BaerBassit shales.

pillow lavas are depositionally underlain by turbiditic calcarenites (packstones) containing intervals of reworked shallow-water carbonate, up to $20 \mathrm{~m}$ thick (e.g. near Al-Wadi village; Fig. 2). These limestones were also dated as Late Triassic in age by DelauneMayère \& Saint-Marc (1979/80). West of Al-Wadi village, highly sheared pillow lavas are overlain by massive pink micritic limestone. Similar pillow lavas are exposed at Qastal Maaf, Qarannia and close to Kizel Jouret el Azhari villages in the far south (Fig. 2), where they reach 10-20 m thick within intact units.

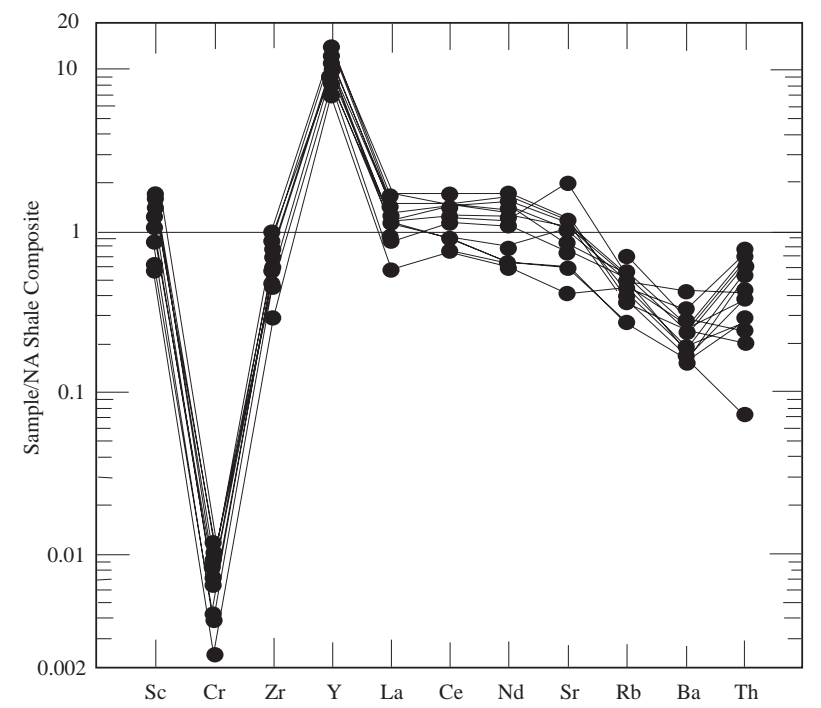

Figure 10. Representative terrigenous shale samples (unrelated to coeval volcanism), normalized against the North American Shale composite (Gromet et al. 1984). Normalizing values (ppm): Sc 14.90, Cr 12450, Zr 200, Y 2.10, La 31.10, Ce 66.70, Nd 27.40, Sr 142, Rb 125, Ba 636, Th 12.30 .

\section{5.b. Middle Jurassic-Lower Cretaceous lavas}

Middle Jurassic-Lower Cretaceous lavas, associated intrusive rocks and volcaniclastic sedimentary rocks are present in several areas, bounded above and below by tectonic contacts. Alkaline lavas were dated at $150 \mathrm{Ma}$ by the K/Ar method (Delaloye \&Wagner, 1984). Radiolarites intercalated with fine-grained volcaniclastic sediments below and basalt above at Beit El-Qaddar (Fig. 12b) yielded Early Cretaceous radiolaria (Al-Riyami et al. 2000; Al-Riyami, Danelian \& Robertson, in press).

The thickest and largest exposed volcanogenic unit is in the Tammima area ('Tammima Formation' of Parrot, 1974b). Tectonically deformed lavas and intrusive rocks there are interbedded with radiolarian cherts and shales (Delaune-Mayère, 1984), with a total thickness of 150-200 m (Parrot, 1974b; Fig. 13). The volcanic rocks form a large, internally disrupted thrust sheet, underlain by ophiolitic peridotite and overlain by a thick thrust sheet of peridotite and gabbro (part of the Baer ophiolitic massif; Fig. 2). Local successions of lavas interbedded with chert were measured in the Tammima area during this study (Fig. 12b). Three lava types were recognized: (1) kaersutitic-bearing clinopyroxene-olivine-phyric lavas forming large vesicular pillow lavas in units up to $8 \mathrm{~m}$ thick; (2) kaersutite-free clinopyroxene-phyric lavas forming small amygdaloidal, locally tube-like pillows (30-50 cm); (3) dark-green aphyric pillow lavas. Detailed petrographic descriptions are given by Al-Riyami (unpub. Ph.D. thesis, Univ. Edinburgh, 2000). 


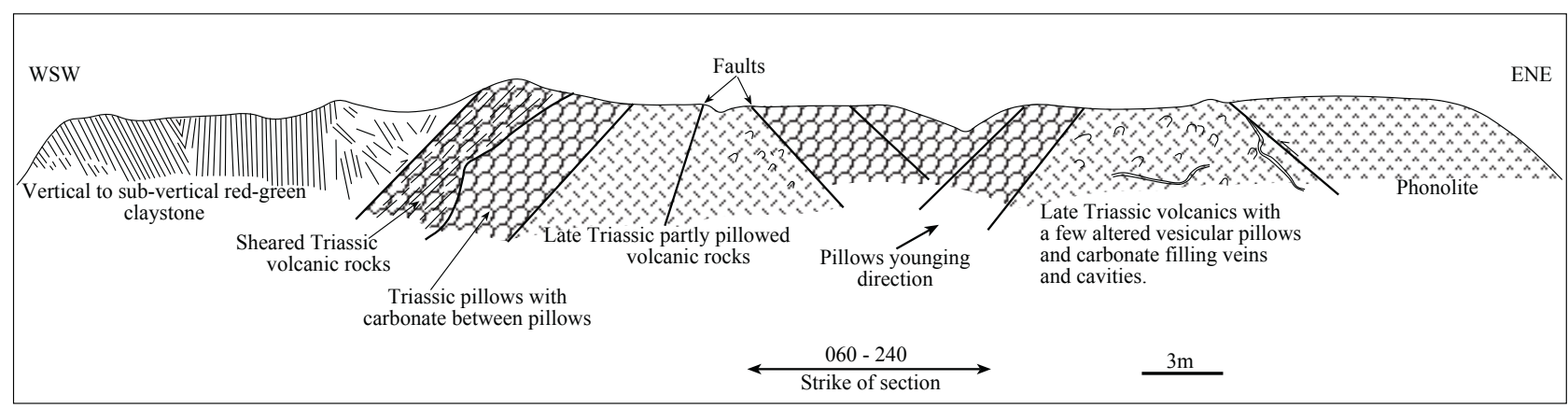

a

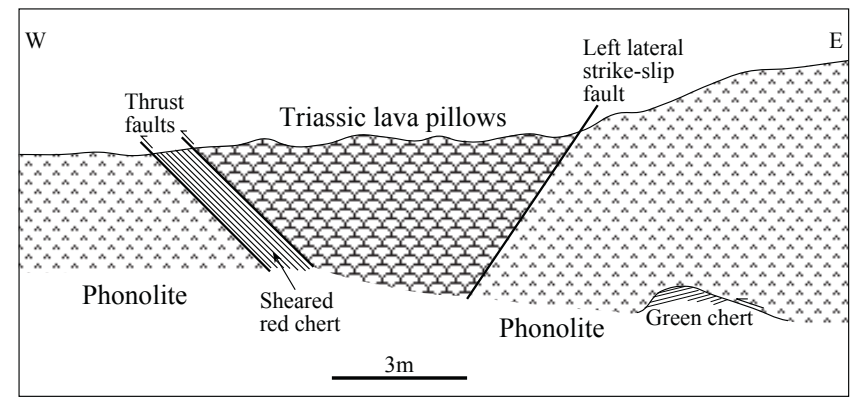

b

Figure 11. Sketch sections of the Upper Triassic extrusive rocks in tectonic contact with other melange lithologies. (a) From Qarannia area; (b) from Qastal Maaf area (Fig. 2). See text for explanation.

Whole-rock chemical analysis confirms an alkaline composition (Fig. 14a; Table 2). The extrusives are chemically very similar to the protoliths of the overlying metamorphic sole (Al-Riyami et al. in press). Petrogenetic aspects of the melange volcanic rocks and sole metavolcanic rocks are discussed elsewhere (Al-Riyami et al. in press).

The cores and rims of co-existing kaersutite (aluminous titanian amphiboles) and titanaugite phenocrysts in basalts from Tammima were analysed using an electron microprobe (K. Al-Riyami, unpub. Ph.D. thesis, Univ. Edinburgh, 2000). The composition of the kaersutite is remarkably constant, with $\mathrm{Al}_{2} \mathrm{O}_{3}$ close to $13 \%$ and $\mathrm{TiO}_{2}$ from $4.5-6.5 \%$ in cores and $5.5-7.1 \%$ in rims. Co-existing pyroxenes are zoned aluminous titanaugites, ranging from $2.5-9.2 \% \mathrm{Al}_{2} \mathrm{O}_{3}$ in cores to $6.5 \%$ to $9.3 \% \mathrm{Al}_{2} \mathrm{O}_{3}$ in rims. $\mathrm{TiO}_{2}$ contents vary from $2.5-3.8 \mathrm{wt} \%$. Compositional trends in individual crystals mirror those in the amphiboles with rim compositions richer in $\mathrm{Ti}$ and $\mathrm{Al}$ compared to the cores. Such compositions are typical of ocean island or some rift lavas (Wilson, 1989).

Representative samples of relatively unaltered basalts were collected from both the sparse Late Triassic exposures and from the much more extensive exposures of mid-Jurassic to Early Cretaceous age, as exposed in the Tammima area (Fig. 13). The aim was to shed light on their eruptive tectonic setting using standard immobile element discriminant plots (Pearce, 1982, 1996; Table 1). When the data are plotted on Mid-Ocean Ridge Basalt (MORB) normalized 'spidergrams' (Pearce, 1982, 1996) they show typical humped patterns of 'enriched' alklaline basalts (Fig. 15). The most incompatible high field strength element, $\mathrm{Nb}$ is enriched up to 60 times relative to MORB. The 'spidergrams' also show a negative slope between $\mathrm{Zr}$ and $\mathrm{Ti}$. Magmatic discrimination diagrams (Fig. $14 \mathrm{c}, \mathrm{d}$ ) confirm the strongly alkaline to per-alkaline nature of the melange extrusives (Parrot, 1974b) and indicate a within plate-type tectonic setting.

\section{5.c. Phonolite}

Small bodies of phonolite are present only in the northern part of the area (near Fillik, Qantarra, Qastal Maaf and Qarannia; Fig. 2). The phonolites usually form small faulted outcrops, the largest of which $\left(2000 \mathrm{~m}^{2}\right)$ is near the village of Fillik. Parrot (1974b) interpreted the phonolites as flows. However, their location, distribution and absence of extrusive features (e.g. internal flow banding) favour an intrusive origin, albeit at very high level near the sea-floor. The phonolites are fine-grained, massive, grey-pink rocks, locally containing rare phenocrysts and locally exhibiting trachytic and blastoporphyritic textures. The phonolites and nepheline syenites typically contain potash feldspar (34\%), nepheline (17\%), plagioclase $(12 \%)$, glass $(24 \%)$ and secondary minerals (Parrot, 1974b). These rocks are assumed to be co- 


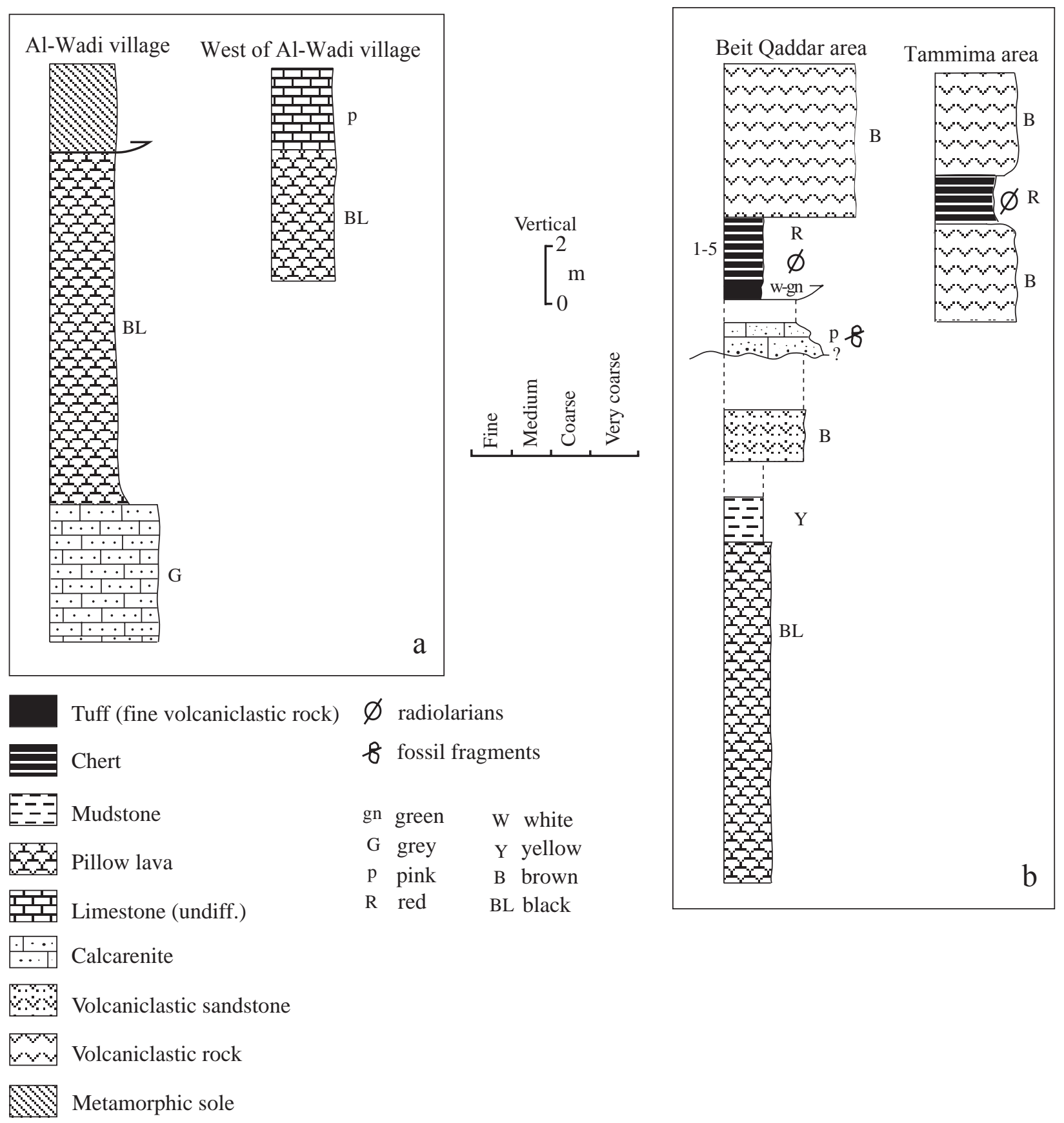

Figure 12. Representative measured logs of (a) the Upper Triassic pillow lavas and other lithologies; (b) Middle Jurassic-Lower Cretaceous volcanic rocks and associated sedimentary rocks. See Figure 2 for locations.

magmatic with, and of the same age as, the associated extrusive sequence.

\section{5.d. Volcaniclastic sedimentary rocks}

The volcanic rocks of Middle Jurassic-Early Cretaceous age are interbedded with three lithofacies of volcaniclastic sedimentary rocks: (1) volcanogenic conglomerates, with mainly volcanic clasts; (2) volcaniclastic sandstones; (3) volcanogenic siltstones and claystones (commonly altered). Most deposits are massive to weakly bedded. In the Tammima area (Fig. 2), clast- to matrix-supported conglomerates are interbedded with radiolarites of Bajocian age. These conglomerates are composed of clasts of basalt, volcaniclastic sandstone, alkaline lava and sub-rounded chert. In the Mazraa and Qastal Maaf areas (Fig. 2) volcaniclastic conglomerates contain clasts of volcaniclastic sandstone, volcanic rocks and chert. Individual clasts are angular (5-7 cm in size) and poorly sorted, set in a fine- to medium-grained sandy matrix. In addition, in the Iman area, a road cutting towards 


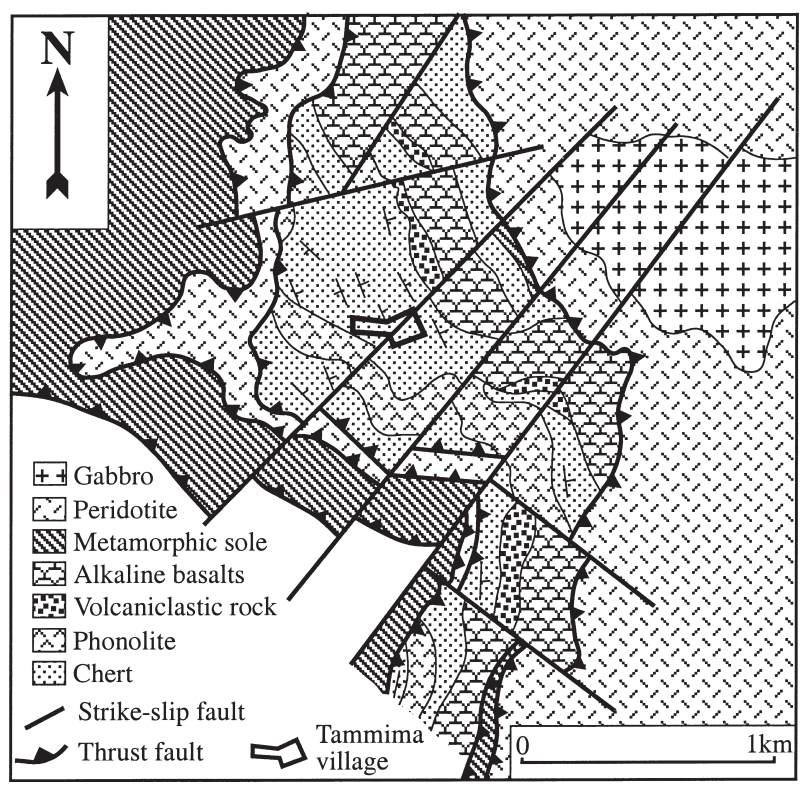

Figure 13. Geological map of the type section of Middle Jurassic-Lower Cretaceous volcanic rocks in the Tammima area, modified after Parrot (1974b).
Al-Ghassaniya village (Fig. 2) exposes massive volcanogenic sedimentary rocks, mainly composed of clasts of lava and nodular pink pelagic limestone, together with chert lenses. Near Kassab in the north (Fig. 2), volcanogenic sediments (10 $\mathrm{m}$ thick) include abundant clasts of alkaline basalt $(2-30 \mathrm{~cm}$ in size) and volcanic glass interbedded with lenses of laminated green chert. Elsewhere, at Beit El-Qaddar, whitegreen sandy volcaniclastic siltstone $(50 \mathrm{~cm}-1 \mathrm{~m}$ thick) is overlain by red chert, then by volcaniclastic conglomerate $(4 \mathrm{~m})$. The volcaniclastic siltstone is composed of crystals (olivine, pyroxene, quartz), glass (globules and irregularly shaped shards) and rock fragments.

\section{5.e. Associated lithologies}

Radiolarian cherts and shales. In the Tammima area (Fig. 13) the volcanic rocks and volcaniclastic sedimentary rocks are commonly interbedded with ribbon radiolarites and non-calcareous reddish and brownish shale (Delaune-Mayère, 1978). At Tammima (Fig. 2),
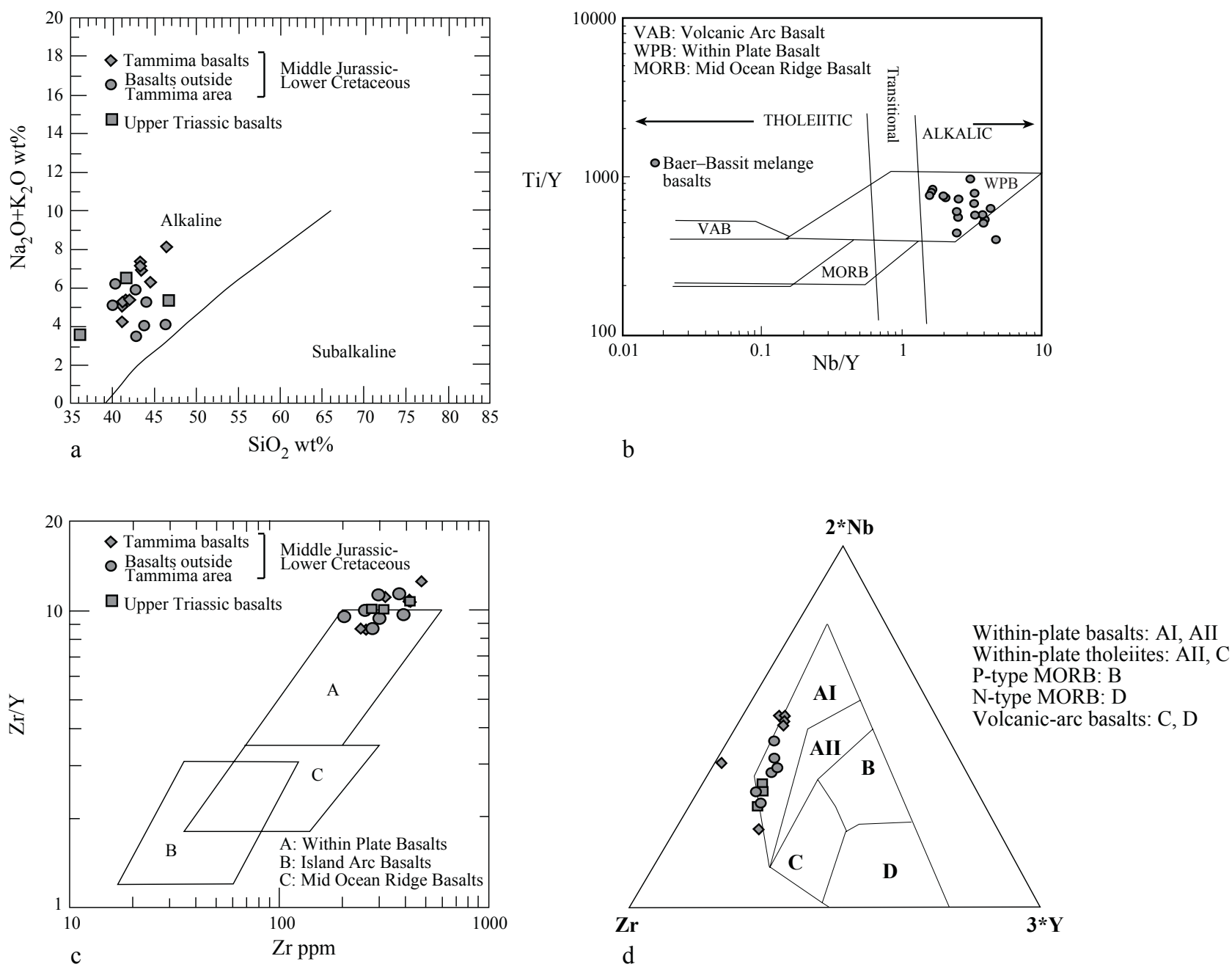

Figure 14. Geochemical diagrams for the Upper Triassic and the Middle Jurassic-Lower Cretaceous volcanic rocks. (a) Harker plot of $\mathrm{Na}_{2} \mathrm{O}+\mathrm{K}_{2} \mathrm{O}$ vs. $\mathrm{SiO}_{2}$; (b) $\mathrm{Ti} / \mathrm{Y}-\mathrm{Nb} / \mathrm{Y}$ (Pearce, 1982); (c) Ti/100, Zr, Y (Pearce \& Cann, 1973); (d) 2Nb-Zr-3Y (Meschede, 1986). See text for explanation. 
Table 2. Representative geochemical analyses of Upper Triassic volcanic rocks and Middle Jurassic-Lower Cretaceous volcanic rocks

\begin{tabular}{|c|c|c|c|c|c|c|c|c|c|}
\hline \multirow[b]{2}{*}{ Sample } & \multicolumn{5}{|c|}{ Tammima Upper Triassic } & \multicolumn{4}{|c|}{ Tammima Middle Jurassic-Lower Cretaceous } \\
\hline & $98 / 1$ & $98 / 44$ & $98 / 163$ & $98 / 206$ & $98 / 213$ & $98 / 205$ & $98 / 211$ & $98 / 212$ & $\mathrm{~F} 2 / 1$ \\
\hline $\mathrm{SiO}_{2}$ & 36.13 & 46.71 & 41.62 & 41.4 & 39.99 & 41.07 & 43.75 & 42.75 & $4 \mathrm{Z} .79$ \\
\hline $\mathrm{Al}_{2} \mathrm{O}_{3}$ & 12.9 & 15.27 & 14.76 & 12.93 & 11.8 & 14.7 & 14.25 & 15.54 & 11.08 \\
\hline $\mathrm{Fe}_{2}^{2} \mathrm{O}_{3}^{3}$ & 15.01 & 12.7 & 12.47 & 11.49 & 12.08 & 14.23 & 12.72 & 12.78 & 10.02 \\
\hline $\mathrm{MgO}^{2}$ & 6.44 & 5.76 & 5.34 & 6.51 & 6.62 & 4.25 & 7.06 & 7.18 & 7.13 \\
\hline $\mathrm{CaO}$ & 12.95 & 7.99 & 9.2 & 12.69 & 12.93 & 8.37 & 10.62 & 5.74 & 15.22 \\
\hline $\mathrm{Na}_{2} \mathrm{O}$ & 1.29 & 4.17 & 5.96 & 3.92 & 2.51 & 3.66 & 3.05 & 4.53 & 2.7 \\
\hline $\mathrm{K}_{2} \mathrm{O}$ & 2.299 & 1.165 & 0.555 & 1.436 & 2.616 & 1.595 & 1.006 & 1.372 & 0.806 \\
\hline $\mathrm{TiO}_{2}$ & 5.079 & 1.995 & 3.747 & 3.234 & 3.521 & 3.939 & 3.156 & 3.75 & 2.693 \\
\hline $\mathrm{MnO}$ & 0.298 & 0.183 & 0.331 & 0.201 & 0.347 & 0.194 & 0.178 & 0.358 & 0.109 \\
\hline $\mathrm{P}_{2} \mathrm{O}_{5}$ & 0.747 & 0.574 & 0.921 & 0.74 & 0.615 & 0.506 & 0.593 & 0.963 & 0.435 \\
\hline LOI & 6.28 & 2.62 & 4.59 & 5.02 & 6.09 & 7.03 & 3.23 & 4.36 & 6.6 \\
\hline Total & 99.43 & 99.14 & 99.5 & 99.58 & 99.12 & 99.54 & 99.6 & 99.33 & 99.59 \\
\hline $\mathrm{Nb}$ & 96.6 & 69.9 & 140.8 & 117.2 & 88.8 & 49.1 & 81.3 & 104.9 & 45.6 \\
\hline $\mathrm{Zr}$ & 309.4 & 272.9 & 416.4 & 374.1 & 295.7 & 256.7 & 299 & 388.7 & 205.2 \\
\hline $\mathrm{Y}$ & 30.7 & 27.2 & 39.2 & 33.8 & 26.4 & 30 & 31.4 & 40.3 & 21.7 \\
\hline $\mathrm{Sr}$ & 296.6 & 622.2 & 526.7 & 558.7 & 703.9 & 578.3 & 708.6 & 644.6 & 408.8 \\
\hline $\mathrm{Rb}$ & 46.5 & 28.7 & 11 & 34.4 & 34.8 & 30.8 & 11.9 & 16.2 & 21.8 \\
\hline $\mathrm{Th}$ & 7 & 5.8 & 10.2 & 8.7 & 7.3 & 3.5 & 9.7 & 9.9 & 5.2 \\
\hline $\mathrm{Pb}$ & 2.6 & 3.4 & 4 & 4 & 3.6 & 0.7 & 4.3 & 3.4 & 2.2 \\
\hline $\mathrm{Zn}$ & 116.6 & 126.4 & 134.7 & 117.2 & 94.3 & 89.2 & 113.1 & 131.9 & 121.4 \\
\hline $\mathrm{Cu}$ & 48.3 & 40.7 & 42.1 & 69.4 & 142.1 & 38.1 & 88.4 & 42.1 & 61.7 \\
\hline $\mathrm{Ni}$ & 21 & 113.3 & 29 & 151.9 & 71.1 & 59.8 & 77.9 & 38.4 & 131.8 \\
\hline $\mathrm{Cr}$ & 2.8 & 149.9 & 16.9 & 346.6 & 65.4 & 23.3 & 125.5 & 28.1 & 179.9 \\
\hline $\mathrm{Ce}$ & 141 & 103.7 & 186.4 & 198.6 & 126.3 & 92.9 & 123.5 & 147.3 & 71.6 \\
\hline $\mathrm{Nd}$ & 66.2 & 41.9 & 82.7 & 75.3 & 57 & 44.6 & 52.3 & 64.4 & 36.5 \\
\hline $\mathrm{La}$ & 56.7 & 53.9 & 92.8 & 107.9 & 51.3 & 27.8 & 58.4 & 69.3 & 43.5 \\
\hline V & 374.8 & 182.2 & 260 & 284.2 & 375 & 234.7 & 268.3 & 209.6 & 293.6 \\
\hline $\mathrm{Ba}$ & 468.6 & 457.6 & 595.8 & 1050.7 & 1099.1 & 239.1 & 665.2 & 641.5 & 194.2 \\
\hline $\mathrm{Sc}$ & 22.2 & 19.7 & 12.1 & 24.1 & 29.6 & 21.7 & 22.6 & 12.7 & 23.6 \\
\hline
\end{tabular}

Major elements in weight \% oxide; trace elements in ppm. Details of analytical procedures are given in Table 1.

the typical red siliceous sediments give way to yellow shales with layers of recrystallized black chert (5-10 $\mathrm{cm}$ thick). In addition, varicoloured shales and black cherts occur in close vicinity to the extrusive and intrusive rocks, which may be explained by contact metamorphism or hydrothermal alteration.

Ferromanganese-rich carbonates. In the Tammima area the alkaline volcanic rocks and cherts are depositionally overlain by dark manganese oxide-rich crusts (Fig. 8e) and fine-grained siliceous limestones (6 m), passing traditionally upwards into pink nodular and stylolitic pelagic limestone $(6 \mathrm{~m})$. The nodules are dispersed throughout a clay and haematite-rich matrix. This matrix contains fragments of thin-shelled bivalves and calcite-replaced radiolarians and was dated as Cenomanian in age by Delaune-Mayère (1984), based on Hedbergella sp., Gavelinellidae, Heterohelix, Pithonella ovalis and Pithonella spaerica.

\section{5.f. Interpretation of the volcanic and related lithologies}

The Late Triassic alkaline volcanic rocks were erupted in a deep-marine setting where the background sedimentation was non-calcareous radiolarian mud and radiolarite. The intercalations of fine-grained Halobia limestone imply input of carbonate ooze from an adjacent carbonate platform, for which the Arabian platform to the south is the only known source. In addition, the occurrence of calciturbidites (with neritic grains), depositionally underlying the pillow lavas, shows that some eruptions occurred relatively near to a source of shallow-water carbonate. The Middle Jurassic-Early Cretaceous volcanic rocks are compositionally identical to their Upper Triassic counterparts, although locally more evolved to per-alkaline rocks (nephelinite and phonolite). Interbedded pelagic sedimentary rocks are mainly non-calcareous radiolarian sediments, pointing to an open-marine setting, removed from gravity input of coarse margin-derived sediment. The magmatic activity built up one, or several, submarine edifices, $>200 \mathrm{~m}$ thick. During and after eruption, volcanogenic material underwent subaqueous erosion and mass wasting giving rise to localized volcaniclastic talus, debris flows, volcanogenic muds, silts and sands. After volcanism ended in the type (Tammima) area $\mathrm{Fe}-\mathrm{Mn}$-rich oxide-sediments and carbonate oozes of Cenomanian age accumulated above the lavas, and were later diagenetically altered to nodular limestone with ferromanganese segregations.

\section{Structure and tectonic emplacement}

The Baer-Bassit melange is composed of detached blocks, broken formation and dismembered thrust 
sheets (Fig. 3). The chaotic nature is increased by the effects of widespread Neogene strike-slip faulting (Figs 2, 3). The dips and strikes and way-up of bedding (where determinable) and the geometry of outcropscale folds within the melange were measured during this study. Fold facing and fold vergence (where wayup criteria were not available) were also measured. The results show that large-folds are upward-facing. Facing and vergence directions show a wide spread as expected for a melange, but mainly imply emplacement towards the southeast (Fig. 16a-d).

The Baer-Bassit melange is restored as the relatively proximal segment of a rifted passive margin of the South-Tethys ocean (Fig. 4). Within more axial areas of this ocean, oceanic crust formed, represented by the Baer-Bassit Ophiolite. Geochemical evidence indicates that this oceanic crust formed above a subduction zone that is assumed to have been northward-dipping (Al-Riyami et al. 2000, in press; Fig. 4). The age of this oceanic crust is assumed to be Late Cretaceous, comparable to other ophiolites in the region, including the Troodos ophiolite (Musaka \& Ludden, 1987). However, this is presently constrained only by the $\mathrm{K}-\mathrm{Ar}$ radiometric ages (85-95 Ma) of the metamorphic sole (Whitechurch \& Parrot, 1978; Delaloye \& Wagner, 1984), together with preliminary palaeomagnetic dating (Morris et al. 1999).

After accumulation of the youngest dated sediments on the Arabian margin, of Maastrichtian age, the deepwater sedimentary and volcanic rocks of the BaerBassit Melange were detached from their presumed oceanic basement and emplaced southeastwards onto the Arabian margin. The deep-water sediments and volcanic rocks were initially emplaced within an accretionary prism related to northward-directed subduction (Fig. 4). This deformation was of low-temperature type, characterized by thrusting, shearing and brittletype folding (Figs 8f, 16a-d).

During the later stages of emplacement onto the Arabian continental margin the accretionary wedge was tectonically imbricated with the Baer-Bassit Ophiolite, giving rise to complicated out-of-sequence thrusting (Al-Riyami et al. 2000) and tectonic rotations. The only known possible depositional record accompanying the subduction-accretion and emplacement history is a localized occurrence of poorly consolidated polymict, matrix-supported volcaniclastic debris flows ('olistostromes'), up to $40 \mathrm{~m}$ thick near Zhitounah village (Fig. 2). These sediments contain clasts of carbonate rocks, chert, volcanic rocks and ophiolitic gabbro set in variably sheared shaly matrix. This material is inferred to record mass wasting of material derived from both the Baer-Bassit Melange and the ophiolite during its tectonic emplacement over the Arabian continental margin. Emplacement ended by Late Maastrichtian time when shallow-water detrital and carbonate deposition resumed above the emplaced allochthonous rocks (Kazmin \& Kulakov, 1968).

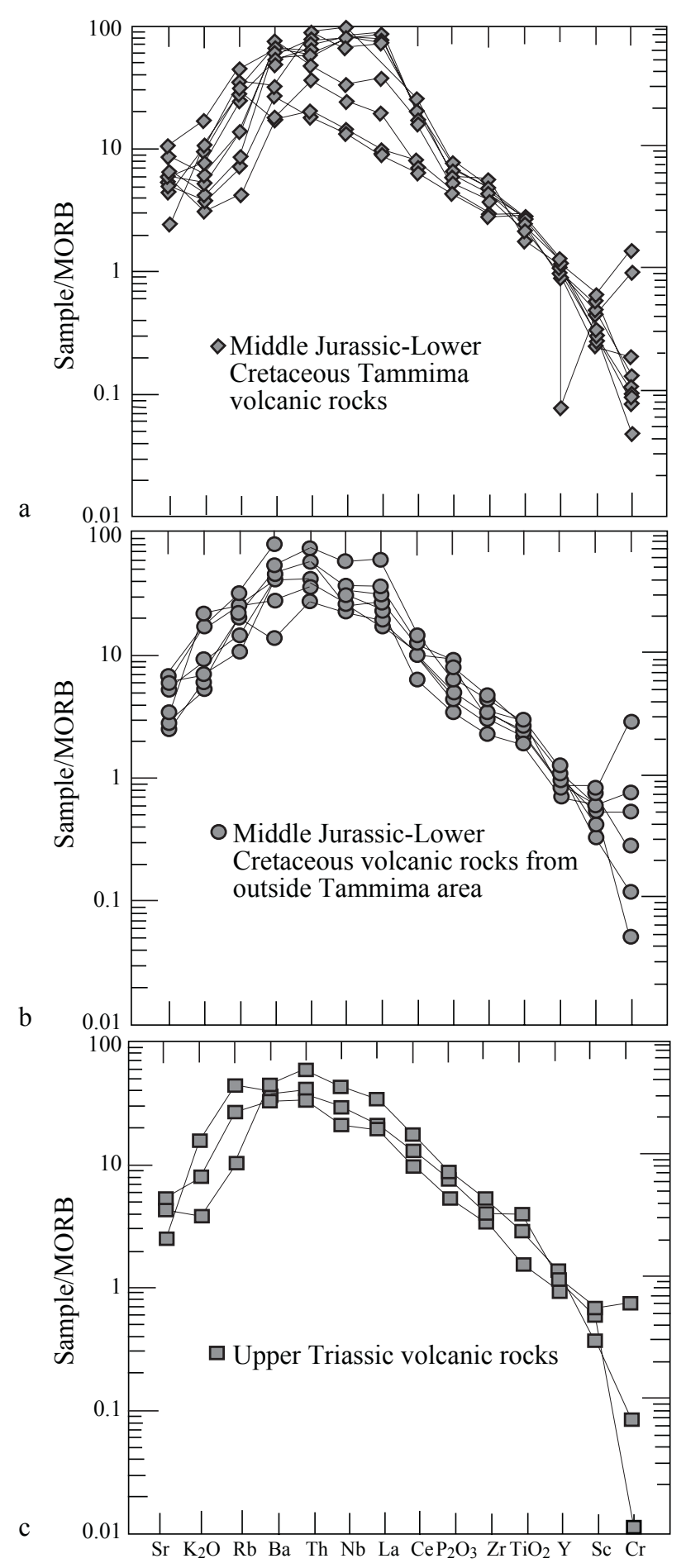

Figure 15. MORB-normalized incompatible element diagrams for basalt samples from the Baer-Bassit Melange (Pearce, 1982, 1996). Normalizing values: $\mathrm{Sr} 122$ ppm, $\mathrm{K}_{2} \mathrm{O}$ 0.15 ppm, Rb 1.12 ppm, Ba 14.3 ppm, Th 0.185 ppm, Nb $3.58 \mathrm{ppm}$, La 3 ppm, Ce 11.97 ppm, $\mathrm{P}_{2} \mathrm{O}_{5} 0.12 \%$, Zr 90 ppm, $\mathrm{TiO}_{2} 1.5 \%$, Y $34.2 \mathrm{ppm}$.

\section{The Baer-Bassit Melange restored as a passive margin/ocean basin transition}

The Baer-Bassit Melange can be reconstructed to its Mesozoic pre-emplacement setting based on the following lines of evidence: (1) The sedimentary and 

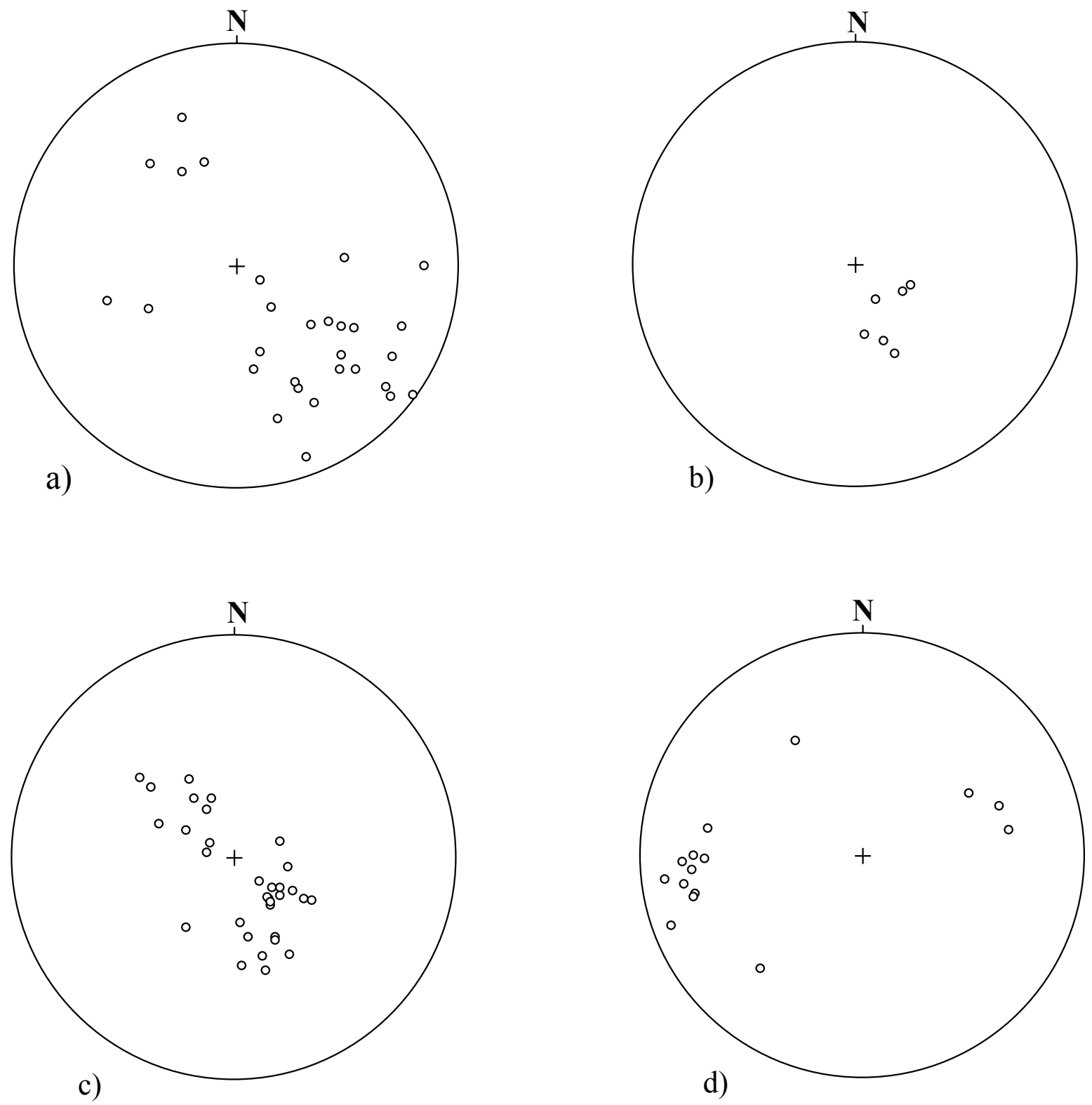

Figure 16. Structural data from the melange. (a) Poles to fold axial planes; (b) poles to thrust planes within blocks and broken formation; (c) Plpoles to thrust contacts; (d) poles to shear planes within the melange. Overall emplacement towards the southeast is inferred, as supported by additional data from the overlying metamorphic sole of the ophiolite (Al-Riyami et al. in press).

volcanic units can be restored as an overall succession ranging in age from Late Triassic to Cenomanian. However, marked local facies variation existed along and across the rifted passive margin (Fig. 6). (2) The mainly sedimentary successions accumulated near the base of the slope of a carbonate platform, as confirmed by the gravity input of coarse neritic-derived sediments in the Late Triassic and Cretaceous intervals. (3) The Middle Jurassic to Lower Cretaceous volcanic rocks of the Tammima formation lack coarse margin-derived sediment, reflecting an inferred origin as one or more seamounts within the oceanic basin.

Our preferred palinspastic restoration is that the most proximal preserved successions accumulated along the base of slope of the rifted Arabian continental margin. The nature of the basement beneath is unknown. These marginal successions lacked thick volcanic successions of Jurassic-Early Cretaceous age. By contrast, the alkaline volcanic rocks of Middle Jurassic-Early Cretaceous age were erupted further from the margin where the main background deposition was siliceous radiolarian ooze and muds (Fig. 17). However, some of the proximal units (e.g. the Kebir formation south of Ain Al-Kebira; Fig. 2) contain redeposited alkaline volcaniclastic sediment, suggesting a local volcanic source. Also, the Triassic coarse 


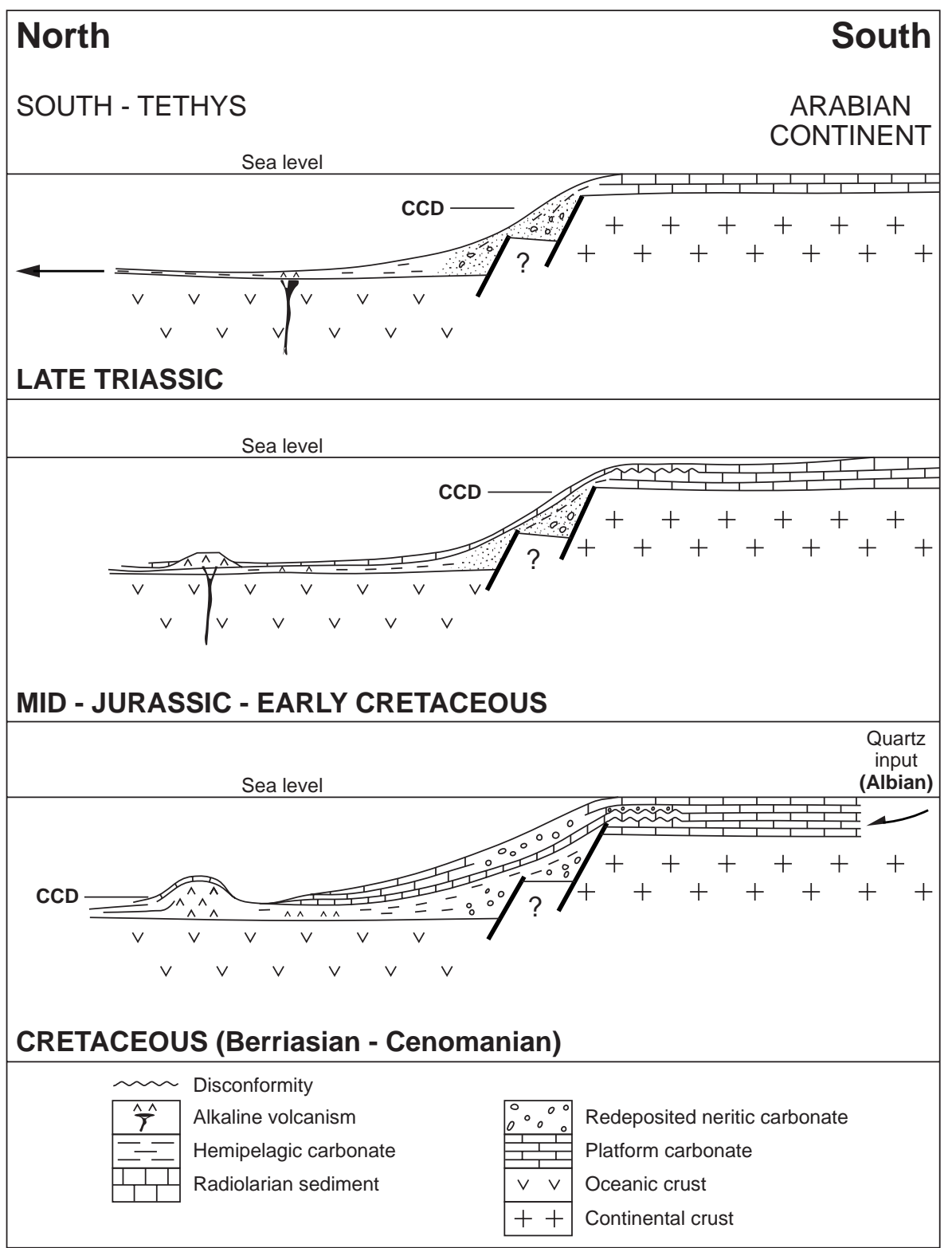

Figure 17. Tectonic reconstructions of the Baer-Bassit margin/oceanic units in northern Syria, prior to emplacement onto the Arabian margin in latest Cretaceous time. See text for explanation.

platform-derived carbonates are locally interstratified with alkaline lava suggesting the basement may be rift volcanic rocks. The relatively distal Middle JurassicLower Cretaceous extrusive succession was locally overlain by $\mathrm{Fe}-\mathrm{Mn}$ oxide crusts and nodular pelagic limestones, consistent with formation of a seamount that was isolated from margin-derived gravity deposited sediment. In summary, a relatively marginal, rather than open-ocean, oceanic setting is favoured for all of the melange units.

\section{Regional comparisons}

\section{8.a. Rift-massive margin evolution}

The Baer-Bassit Melange shows similarities in lithostratigraphy with the Mamonia Complex of southwestern Cyprus and with the Antalya Complex of southwestern Turkey, also with other Mediterranean Tethyan margin successions (Delaune-Mayère et al. 1977; Dercourt et al. 1986; Robertson et al. 1991; Al-Riyami et al. 2000; Stampfli et al. 2001). However, there are some distinctive features in Baer-Bassit: (1) Quartzose sandstones are much more abundant in Cyprus and southern Turkey in the Late Triassic and Early Cretaceous interval than in Baer-Bassit. (2) Late Triassic shallow-water 'exotic' limestones, as in southwestern Cyprus and Antalya are not known in Baer-Bassit. (3) The structure in each of the three areas mentioned above differs markedly. The BearBassit Melange is interpreted as part of the Arabian passive margin/ocean basin, whereas counterparts in southwestern Cyprus and southwestern Turkey are seen as parts of the conjugate (northern) margins of a South-Tethyan oceanic basin (Robertson, 1998). 
Regional comparisons suggest that rifting in the easternmost Mediterranean region may have begun as early as Late Permian time, continuing through Early-Middle Triassic time. However, continental break-up was not completed until the Late Triassic (Carnian-Norian), marked by the genesis of transitional to MORB-type extrusives in western Cyprus and southwestern Turkey (Malpas, Calon \& Squires, 1993; Robertson \& Waldron, 1990). Assuming a similar history for neighbouring northern Syria, continental break-up occurred in the Late Triassic, and thus, the Late Triassic deep-water sediments of the BaerBassit Melange formed along a rifted margin, either above marginal oceanic crust or above thinned continental crust, not now exposed. Shelf-derived carbonate debris flows and calciturbidites, accumulated on a subsiding passive margin after continental break, explaining their overall fining-upward character. Notably, the Triassic units contain coarse shelf-derived calcarenites and calcirudites, whereas (locally overlying) Jurassic successions are much finer grained.

The Baer-Bassit, South-Tethyan units can also be compared with the Hawasina Complex in Oman (Lippard, Shelton \& Gass, 1986; Robertson \& Searle, 1990). Although far to the southeast (Fig. 1), this is the only other well-documented area of emplaced Arabian margin/oceanic units. However, there are a number of obvious dissimilarities: (1) There was a phase of Permian volcanism and deep-basin opening in Oman which is unknown in the easternmost Mediterranean, including northern Syria. (2) The platform edge is well exposed in Oman (Sumeini Group), but in northern Syria it is buried beneath the Tethyan allochthon. (3) The structurally underlying carbonate platform is very well exposed (e.g. Jebel Akhdar) in Oman, but is only locally exposed in northern Syria (in Jebel Aqraa; Fig. 8a) and even there only from the Lower Jurassic onwards (Kazmin \& Kulakov, 1968). (4) The phase of Middle Jurassic-Lower Cretaceous alkaline/per-alkaline eruption in northern Syria is unknown in Oman, although alkaline basalts of Cenomanian age are locally present in distal units (e.g. in the Dibba and Hatta zones) of the northern Oman Mountains (Robertson \& Searle, 1990). (5) The Baer-Bassit melange is more complex structurally relative to the Hawasina Complex which can be partially restored assuming in-sequence thrusting, and which did not experience pervasive later strike-slip faulting.

Despite the above differences between the BaerBassit and Oman regions, some interesting generalizations can be made for these two regions of the Arabian continental margin. The Late Triassic successions in both regions include carbonate debris flows, calciturbidites and periplatfrom oozes (that is, in the Sumeini Group, Oman). In Oman, these carbonates are interpreted to have accumulated on a distally steepened slope marked by small submarine fans (Watts \&
Garrison, 1986). The Upper Triassic background sediments in Baer-Bassit are comparable to the Hamrat Duru Group in Oman where radiolarian chert is abundant (e.g. Zulla Formation, Unit 3; Cooper, 1990; I. Blechschmidt, in Blechschmidt \& Robertson, 2001). The Syrian pelagic and reworked limestones near the top of the Late Triassic succession could be equivalent to the micritic and arenitic limestone with pelagic bivalves and interbedded shale of the Zulla Formation, Unit 4 in Oman (I. Blechschmidt, in Blechschmidt \& Robertson, 2001). However, there is no obvious equivalent in northern Syria of a major unit of terrigenous quartzose sandstone and shale of Late Triassic-Early Jurassic age (Guweyza Sandstone Formation) in Oman (Cooper, 1990; I. Blechschmidt, in Blechschmidt \& Robertson, 2001). The Middle to Late Jurassic interval is mainly siliceous in northern Syria, but contains very much more redeposited limestone in Oman (Guweyza Limestone Formation). In Oman, ribbon cherts dominate in discrete time intervals (e.g. Late Jurassic Sid'r Formation) and are interspersed with non-calcareous facies. In both northern Syria and Oman the Cretaceous is dominated by redeposited carbonate and pelagic carbonate (the Nayid Formation in Oman).

\section{8.b. Regional deformation}

The Baer-Bassit Melange is similar to some other Tethyan melanges underlying emplaced ophiolites, including the Upper Jurassic Avdella Melange in the Pindos Mountains of northwestern Greece (Jones \& Robertson, 1991), the Upper Jurassic Pagondas Melange on Evia island, western Greece (Robertson, 1981; Danelian \& Robertson, 2001) and the Upper Cretaceous Lycian Melange in southwestern Turkey (Collins \& Robertson, 1997). The Greek melange units (Pindos, Evia and regional counterparts) are dominated by deformed, relatively proximal, continental margin units. By contrast, the Lycian Melange is mainly composed of more distal margin and oceanic units, whereas more proximal margin units (lowerslope/rise) are preserved as more ordered thrust sheets (Lycian Thrust Sheets).

Where overlying ophiolites are absent, as in the Mamonia Complex of southwestern Cyprus (similar in age to the Baer-Bassit Melange) and the PindosOlonos Nappes of southwestern and western Greece (Fleury, 1980; Degnan \& Robertson, 1998) the emplaced continental margin units are mainly preserved as long stratigraphically coherent successions within broken formation or repeated thrust sheets rather than as melange. In common with some other melanges, including those of the Indus Suture Zone in Ladakh, northern India (Robertson, 2000), the complexity of the Baer-Bassit Melange exposures was increased by regional deformation following initial emplacement onto the continental margin. 
The Tethyan melanges mentioned above, including the Baer-Bassit Melange, differ markedly from the better-known circum-Pacific melanges, exemplified by the Cretaceous-Early Tertiary Franciscan Complex, western USA (Cloos, 1984; Cowan, 1985). These units commonly include an extensive matrix dominated by trench-type turbidites, together with blocks of dominantly oceanic facies, including cherts, pillow lavas and seamount-related units. The clasts and matrix commonly experienced both high-pressure and lowpressure metamorphic conditions, in contrast to the uniformly unmetamorphosed nature of the Tethyan examples (excluding the overlying metamorphic soles, where present).

\section{Volcanism and sedimentation on the South-Tethyan margin}

The Late Triassic alkaline volcanism may relate to continental rifting and the break-up of the North African/Arabian margin during, or after, formation of a South-Tethyan oceanic basin (Fig. 17). The Middle Jurassic-Lower Cretaceous alkaline/per-alkaline volcanism is assumed to be plume-related, possibly involving the same magmatic source as the Late Triassic volcanism. Extensive alkaline volcanism of Late Jurassic-Early Cretaceous age is documented further south on the Arabian margin, in Lebanon, Israel and Egypt (Laws \& Wilson, 1997; Garfunkel, 1998). A plausible scenario is that Triassic rifting was triggered by regional plume activity (Dixon \& Robertson, 1999, 2001) and that plume activity resumed in Middle Jurassic-Early Cretaceous time in the same region.

The sedimentary record of the South-Tethyan deepwater margin in northern Syria was influenced by a combination of tectonic processes, magmatism, regional climate, eustatic sea-level change and oceanographic events. The thinning-upward Upper Triassic redeposited carbonate succession is seen as reflecting thermal subsidence of the margin following continental break-up. The background sediments appear to have accumulated beneath a relatively shallow CCD throughout Late Triassic-Early Cretaceous time when regional deepening of the CCD occurred (Fig. 17) (Bosellini \& Winterer, 1975). Possibly because of persistence of relatively high heat flow during Middle Jurassic-Early Cretaceous time, the margin remained buoyant, inhibiting the marginal carbonate factory. During Early Cretaceous time, the Negev and adjacent areas of Lebanon experienced alkaline volcanism, emergence and accumulation of mainly reddish sandstones (Karnub Formation: Garfunkel, 1998). The input of quartzose sand in the Albian to the margin in northern Syria (Kebir formation) could relate to this uplift and erosion, which in turn was probably thermally driven. Uplift of the platform edge could have caused over-steepening and collapse of the neritic calcirudites into the basin to form multiple debris flows, as observed. Following the end of alkaline volcanism, passive margin subsidence resumed in the Late Cretaceous leading to upbuilding of the adjacent Arabian carbonate platform, as exposed in the structurally underlying Jebel Aqraa massif (Kazmin \& Kulakov, 1968; Figs 2, 3), and more widely further south in the Syrian platform (Al-Maleh et al. 1992). As a result, neritic carbonates were shed into the basin, mainly as calciturbidites and periplatform ooze, as seen in the Cenomanian interval within the BaerBassit Melange. In addition, regional oceanic high productivity events stimulated siliceous deposition, especially during Tithonian-Berriasian time (Jenkyns \& Winterer, 1982; De Wever, 1982).

Eustatic sea-level change (Haq, Hardenbol \& Vail, 1987) also played a role, but this signal cannot easily be disentangled from other variables. Two main unconformities interrupt the regional Arabian margin succession (Flexer et al. 1986; Scott, Frost \& Shaffer, 1988). The first during Berriasian-Barremian time may, in part, relate to eustatic sea-level fall, with the lowest sea-level during Middle Valanginian time. However, eustatic sea-level apparently had recovered by Barremian time. This hiatus may in part relate to Early Cretaceous alkaline volcanism and related thermal uplift, as documented in Lebanon and Israel. The second regional hiatus extended from Coniacian to Campanian time, outside the age range recorded in the Baer-Bassit Melange. Cretaceous ophiolite genesis must also have had some effect on the adjacent margin/oceanic basin, but little sedimentary record of this time interval survives in the Baer-Bassit region, other than for localized polymict debris flow deposits.

\section{Conclusions}

The Mesozoic (Late Triassic-Cenomanian) BaerBassit Melange of northern Syria documents deepwater sedimentation and volcanism adjacent to the Arabian continental margin. Based on lithological correlation and biostratigraphic dating of partial successions within the melange it is possible to restore several overall successions, as follows: a mainly sedimentary succession of Upper Triassic redeposited limestones, hemipelagic limestones, radiolarian cherts with localized alkaline pillow volcanic rocks, passing into a mainly siliceous radiolarian chert-rich succession of Jurassic age. This, in turn, was followed by a Lower-Upper Cretaceous succession of channellized carbonates, debris flow deposits, calciturbidites and redeposited periplatform ooze. There was input of redeposited bioclastic limestone, rich in continentally derived quartzose sandstone during mid-Aptian to Late Albian time mainly in the east of the area. The above composite succession is restored to a base-ofslope setting adjacent to the Arabian carbonate platform. A second succession of mainly Middle Jurassic- 
Early Cretaceous age is dominated by one, or several, submarine seamounts of alkaline/per-alkaline volcanic rocks (with small phonolitic intrusions) and volcaniclastic sediments interbedded with ribbon radiolarites. A more distal (but still relatively marginal) setting isolated from input of terrigenous quartzose or neritic carbonate sediment is inferred for this succession. The Middle Jurassic-Early Cretaceous seamount volcanic rocks were capped by $\mathrm{Fe} / \mathrm{Mn}$ oxides and pelagic carbonate in Cenomanian time after volcanism ended. Overall, the Arabian margin deep-water sedimentary and volcanic rocks reflect a complex interplay of variables including post-rift thermal subsidence, plume-inducted thermal uplift, oceanographic siliceous productivity events, eustatic sea-level change and climatic change. However, tectonic/magmatic events exerted the most profound influence.

Acknowledgements. Our thanks go to the Director of the Geological Establishment of Syria, Dr T. Ballani and his predecessor, Dr K. Al-Maleh, for authorizing this study. We thank Dr M. Humedi and Dr A. S. Turkmani for providing much information on the geology of Syria and for helpful discussions. We also thank Shell Syria for logistical support. Prof. S. Tsaila-Monopolis kindly assisted with the identification of calcareous microfossils. We also thank Drs C. Xenophontos and J. E. Dixon for assistance in the field and for discussion. The first author thanks Petroleum Development, Oman for financial support to carry out this work while based at the University of Edinburgh. Y. Cooper assisted with preparing the photographic plate. We are grateful to Dr Paul Degnan and Prof. Darell Cowan for their helpful reviews of the manuscript.

\section{References}

Al-Maleh, K., Delaune-Mayère, M., Monty, M. \& PARROT, J. F. 1992. Relationship of the front of northern Syrian ophiolitic nappes with the platform in the both sides of the Levantine Fault; Baer-Bassit, Kurd Dagh. Comptes Rendus de l'Academie des Sciences (Paris) 314, série II, 1195-1202.

Al-Riyami, K., Danelian, T. \& Robertson, A. H. F. Radiolarian evidence for the age and depositional setting of Mesozoic deep-water siliceous sediments of the Arabian margin (Baer-Bassit region, N Syria). Terra Nova, in press.

Al-Riyami, K., Robertson, A. H. F., Dixon, J. E. \& Xenophontos, C. Origin and emplacement of the Late Cretaceous Baer-Bassit ophiolite and its metamorphic sole in NW Syria. Lithos, in press.

Al-Riyami, K., Robertson, A. H. F., Xenophontos, C., Danelian, T. \& Dixon, J. E. 2000. Mesozoic tectonic and sedimentary evolution of the Arabian continental margin in Baer-Bassit (NW Syria). In Proceedings of the 3rd International Conference on the Geology of the Eastern Mediterranean, Nicosia, Cyprus, September 23-26th, 1998 (eds J. Malpas, C. Xenophontos and A. Panayides), pp. 61-81. Geological Survey Department, Cyprus.

American Geological Institute. 1961. Dictionary of Geological Terms. New York: Dolphin Books.

BeAll, A. C. JR \& Fischer, A. G. 1969. Sedimentology. In Initial Reports of the Deep Sea Drilling Project 1, (eds
M. Ewing et al. ), pp. 521-94. Washington D. C.: U. S. Goverment Printing Office.

BнатіA M. R., 1983. Plate tectonic and geochemical composition of sandstones. Journal of Geology 91, 611-27.

Blechschmidt, I. \& Robertson, A. H. F. 2001. Sedimentary and structural evolution of the Mesozoic Central Oman continental margin/slope basin. Excursion A03. International Conference Geology of Oman, Sultan Qaboos University, Muscat, Sultanate of Oman, 51 pp.

Bosellini , A. \& Winterer, E. L. 1975. Pelagic limestone and radiolarite of the Tethyan Mesozoic: a genetic model. Geology 3, 279-82.

Cloos, M. 1984. Flow melanges and the structural evolution of accretionary wedges. Geological Society of America Special Paper 198, 71-9.

Collins, A. S. \& Robertson, A. H. F. 1997. Lycian melange, southwestern Turkey: an emplaced Late Cretaceous accretionary complex. Geology 25, 255-8.

Cooper, D. J. W. 1990. Sedimentary evolution and palaeoceaographic reconstruction of the Mesozoiic continental rise in Oman: evidence from the Hamrat Duru Group. In The Geology and Tectonics of the Oman Region (eds A. H. F. Robertson, M. P Searle and A. C. Ries), pp. 161-8. Geological Society of London, Special Publication no. 49.

Cowan, D. S. 1985. Structural styles in Mesozoic and Cenozoic melanges in the western Cordillera of North America. Geological Society of America Bulletin 96, 451-62.

DANElian, T. \& Robertson, A. 2001. Neotethyan evolution of eastern Greece (Pagondas Melange) inferred from radiolarian biostratigraphy and the geochmemistry of associated extrusive rocks. Geological Magazine 138, 345-63.

Degnan, P. \& Robertson, A. H. F. 1998. MesozoicTertiary deep-water passive margin sedimentation, Pindos Zone, southern Greece. Sedimentary Geology 117, 33-70.

Delaloye, M. \& Wagner, J. J. 1984. Ophiolities and volcanic activity near the western edge of the Arabian plate. In The Geological Evolution of the Eastern Mediterranean (eds J. E. Dixon and A. H. F. Robertson), pp. 225-33. Geological Society of London, Special Publication no. 17.

Delaune-MAYĖRe, M. 1978. Cherts Mésozoiques du bassin Téthysien oriental: Mineralogie et géochimie des sediments siliceux du secteur de Tammima (NW Syrien). Cahiers de l'O. R. S. T. O. M., série Géologie 10, 191-202.

Delaune-Mayère, M. 1983. Polarities géochimiques paléogeograhie des séries volcano-sedimentaires pelitiques du NW Syrien au Cretacé basal. Cahiers de l'O. R. S. T. O. M., série Géologie 13, 19-30.

Delaune-Mayère, M. 1984. Evolution of a Mesozoic passive continental margin: Bear-Bassit (NW Syria). In The Geological Evolution of the Eastern Mediterranean (eds J. E. Dixon and A. H. F. Robertson), pp. 151-9. Geological Society of London, Special Publication no. 17.

Delaune-Mayère, M., Marcoux, J., Parrot, J.-F. \& Poisson, A. 1977. Modèle d'évolution mésozoique de la paleo-marge téthsienne au niveau des nappes radiolaritiques et ophiolitiques de Taurus Lycien, d'Antalya et $\mathrm{du}$ Baer-Bassit. International Symposium on the Mediterranean Basins, Split, 1976, pp. 79-94. Editions Technip. 
Delaune-Mayère, M. \& Saint-Marc, P. 1979/80. Données stratigraphiques nouvelles sur les sediments oceaniques Mésozoiques associées aux nappes ophiolitiques du Baer-Bassit (N. W. Syrien). Cahiers de l'O. R. S. T. O. M., série Géologie 11, 151-64.

Dercourt, J., Zonenshain, L. P., Ricou, L. E., Kazmin, V. G., Le Piehon, X., Knipper, A. L., Grandjacquet, C., Sbortshhikov, I. M., Geyssant, J., Leprrier, C., Perchersky, D. H., Boulin, J., Sibuet, J. C., Savostin, L. A., Sorokhtin, O., Westphal, M., Bashrov, M. L., LAuer, J. P. \& BiJu-Duval, B. 1986. Geological evolution of the Tethys belt from the Atlantic to the Pamirs since the Lias. Tectonophysics 123, 241-315.

De Wever, P. 1982. Radiolaires du Trias et du Lias de la Téthys (Systématique, Stratigraphie). Societé Géologique de Nord, Special Publication 7, 599 pp.

Dixon, J. E. \& Robertson, A. H. F. 1999. Are multiple plumes implicated in the Triassic break-up of the Gondwanan Margin in the Eastern Mediterranean region? Journal of Conference Abstracts, 10th European Union of Geosciences 4 (1), 314.

Dixon, J. E. \& Robertson, A. H. F. 2001. A combined plume-influenced and and slab-pull model for Late Triassic continental break-up in the Eastern Mediterranean Region. Journal of Conference Abstracts, 11th European Union of Geosciences 6 (1), 732.

Dubertret, L. 1955. Géologie des roches vertes du NW de la Syrie et du Hatay (Turquie). Notes et Mémoires $d u$ Moyen Orient 6, 13-179.

Fitton, J. G., SAunders, A. D., LARSen, L. M., HARdARSON, B. S. \& NorRY, M. S. 1998. Volcanic rocks of the southeast Greenland margin. Proceedings ODP Scientific Results 152, 331-50.

FleurY, J.-J. 1980. Evolution d'une platform d'un bassin dans leur cadre alpin: Les zones de Gavrovo-Olonos (Grèce continental) et du Pinde-Olonos. Societé Géologique de Nord 4, 1-651.

Flexer, A., Rosenfeld, A., Lipson-BenitAh, S. \& Honigstein, A. 1986. Relative sealevel changes during the Cretaceous in Israel. American Association of Petroleum Geologists Bulletin 70, 1685-99.

GARFUnKel, Z. 1998. Constraints on the origin and history of the Eastern Mediterranean basin. Tectonophysics 298, 5-36.

Glennie, K. W., Boeuf, M. G. A., Hughes-Clarke, M. W., Moody-Stuart, M., Pilaar, W. F. H. \& ReINHARDT, B. M. 1974. Geology of the Oman Mountains. Verhandelingen Koninklijk Nederlands geologisch mijnbouwkundig Genootschap 31, 423 pp.

Gromet, L. P., Dymek, R. F., Haskin L. A. \& Korotev, R. L. 1984. The North American Shale Composite: its compilation, major and trace element characteristics. Geochimica et Cosmochimica Acta 48, 2469-82.

HaQ, B. U., Hardenbol, J. \& VAIL, P. R. 1987. The chronology of fluctuating sea level since the Triassic. Science 235, 1156-67.

Jenkyns, H. C. \& Winterer, E. L. 1982. Palaeoceanography of Mesozoic ribbon radiolarites. Earth and Planetary Science Letters 50, 351-75.

Jones, G. \& Robertson, A. H. F. 1991. Tectono-stratigraphy and evolution of the Mesozoic Pindos Ophiolite and related units, Northwestern Greece. Journal of the Geological Society, London 148, 267-88.

Kazmin V. G. \& Kulakov, V. V. 1968. The geological map of Syria. Scale 1:50,000 (Sheet Al-Latheqiyeh). Explanatory note. Technoexport, Nedra, Moscow, $124 \mathrm{pp}$.
Krasheninnikov, V. A. 1994. Stratigraphy of the Maastrichtian and Cainozoic Deposits of the Coastal Part of Northwestern Syria (Neoautochthon of the Bassit ophiolite Massif). In Geological Structure of the Northeastern Mediterranean (Cruise 5 of the Research Vessel Akademik Nikolaj Strakhov) (eds V. A. Krasheninnikov and J. K. Hall), pp. 265-76. Historical Productions-Hall Ltd.

LaWs, E. \& Wilson, M. 1997. Tectonics and magmatism associated with Mesozoic continental magmatism in the Middle East. Journal of the Geological Society, London 154, 459-64

Lippard, S. J., Shelton, A. W. \& Gass, I. G. 1986. The Ophiolite of Northern Oman. Geological Society of London, Memoir, $178 \mathrm{pp}$.

Malpas, J., Calon, T. \& SQuires, G. 1993. The development of the Late Cretaceous microplate suture in SW Cyprus. In Magmatic Processes and Plate Tectonics (eds H. M. Prichard, T. Alabaster, N. B. Harris and C. R. Neary), pp. 177-98. Geological Society of London, Special Publication no. 70

Meschede, M. 1986. A method of discriminating between different types of mid-ocean ridge basalts and continental tholeiites with the $\mathrm{Nb}-\mathrm{Zr}-\mathrm{Y}$ diagram. Chemical Geology 56, 207-18.

Morris, A., Anderson, M., Al-Riyami, K., Robertson, A. H. F. \& Dixon, J. E. 1999. First palaeomagnetic results from the Baer-Bassit ophiolite of N. Syria. Journal of Conference Abstracts, 10th European Union of Geosciences 4 (1), 407.

MusAKA, S. B. \& LudDEN, J. N. 1987. Uranium-lead ages of plagiogranites from the Troodos ophiolite, Cyprus, and their tectonic significance. Geology 15, 825-8.

PARrot, J.-F. 1974a. L' assemblage ophiolitique du BaerBassit (Nord-Ouest de la Syrie). Etude pétrographique et géochimique du complexe filonien des laves en coussins qui lui sont associées, et d'une partie des formations éffusives du volcanosédimentaire. Cahiers de l' ORSTOM, série Géologie 6, 94-126.

PARrot, J.-F. 1974b. Le Secteur de Tammima (Tourkmanli): Etude d'une sequence volcano-sédimentaire de la région ophiolitique du Baer-Bassit (Nord-Ouest de la Syrie). Cahiers de l' ORSTOM, série Géologie 6, 127-46.

PArrot, J.-F. 1980. The Baer-Bassit (Northwestern Syria) ophiolitic area. Ofioliti 2, 279-95.

Pearce, J. A. 1982. Trace element characteristics of lava from destructive plate boundaries. In Andesites (ed. R. S. Thorpe), pp. 525-48. J. Wiley \& Sons.

Pearce, J. A. 1996. A users' guide to basalt discrimination diagrams. In Trace Element Geochemistry of Volcanic Rocks: Applications for Massive Sulphide Exploration (ed. D. A. Wyman), pp. 79-113. Geochemical Association of Canada, Short Course Notes no. 12.

Pearce, J. A. \& Cann, J. R. 1973. Tectonic setting of basic volcanic rocks determined using trace element analysis. Earth and Planetary Science Letters 19, 290-300.

Ricou, L.-E. 1971. Le croissant ophiolitique peri-arabe, une ceinture de nappes mises en place au Cretacé supérieur. Revue Géographie Physique et Géologie Dynamique 13, $327-49$.

RoberTSON, A. H. F. 1981. Origin and emplacement of an inferred late Jurassic subduction-accretion complex, Euboea, eastern Greece. Geological Magazine 128, 27-41.

Robertson, A. H. F. 1998. Mesozoic-Tertiary Tectonic Evolution of the Easternmost Mediterranean area: inte- 
gration of marine and land evidence: Proceedings of the Ocean Drilling Program, Scientific Results 160, 723-82.

Robertson, A. H. F. 2000. Formation of melanges in the Indus Suture Zone, Ladakh Himalaya by successive subduction-related, collisional and post-collisional processes during Late Mesozoic-Late Tertiary time. In Tectonics of the Nanga Parbat Syntaxis and the Western Himalaya (eds M. A. Khan, P. J. Treloar, M. P. Searle and M. Q. Jan), pp. 333-74. Geological Society of London, Special Publication no. 170.

Robertson, A. H. F., Clift, P. D., Degnan, P. J. \& Jones, G. 1991. Palaeogeographic and palaeotectonic evolution of the eastern Mediterranean Neotethys. Palaeoceanography, Palaeoclimatology, Palaeoecology 87, 289-343.

Robertson, A. H. F. \& Searle, M. P. 1990. The northern Oman Tethyan continental margin: stratigraphy, structure, concepts and controversies. In The Geology and Tectonics of the Oman Region (eds A. H. F. Robertson, M. P. Searle and A. C. Ries), pp. 3-25. Geological Society of London, Special Publication no. 49.

Robertson, A. H. F. \& Waldron, J. W. F. 1990. Geochemistry and tectonic setting of Late Triassic and Late Jurassic-Early Cretaceous basaltic extrusives from the Antalya Complex, south west Turkey. In International Earth Sciences Congress on Aegean Regions, 1990 (eds M. Y. Savasçin and A. H. Eronat), pp. 279-99. Proceedings no. 2.
Scott, R. W., Frost, H. S. \& Shaffer, B. L. 1988. Early Cretaceous sea-level curves, Gulf coast and Southern Arabia. In Sea-Level Changes: An Integrated Approach (eds C. K. Wilgus, B. S. Hastings, C. G. Kendall, H. W. Posamentier, C. A. Ross and J. C. Van Wagoner), pp. 275-84. Society of Economic Palaeontologists and Mineralogists, Special Publication no. 42.

Stampfli, G., Mosar, J., Favre, P., Pillevuit, A. \& VAnNAY, J.-C. 2001. Permo-Mesozoic evolution of the western Tethys realm. In Peritethyan Rift/Wrench Basins and Passive Margins, IGCP 369 (eds P. Ziegler, W. Cavazza, A. H. F. Robertson and S. Crasquin), pp. 51-108. Bulletin du Musée National d'Histoire Naturelle, Paris no. 6.

Tucker, M. \& Wright, V. P. 1990. Carbonate Sedimentology. Oxford: Blackwell Scientific Publications.

WATts, K. F. \& GARrison, R. E. 1986. Sumeini Group, Oman - Evolution of a carbonate slope on a southTethyan continental margin. Sedimentary Geology 48, $107-68$.

Whitechurch, H. \& Parrot, J. F. 1978. Escailles métamorphiques infraperidotitiques dans le Pinde septentrional (Grèce): croute oceanique, métamorphisme et subduction. Comptes Rendus de l'Academie de France 286, 1491-4.

Wilson, M. 1989. Igneous Petrogenesis: A Global Tectonic Approach. London: Chapman and Hall. 